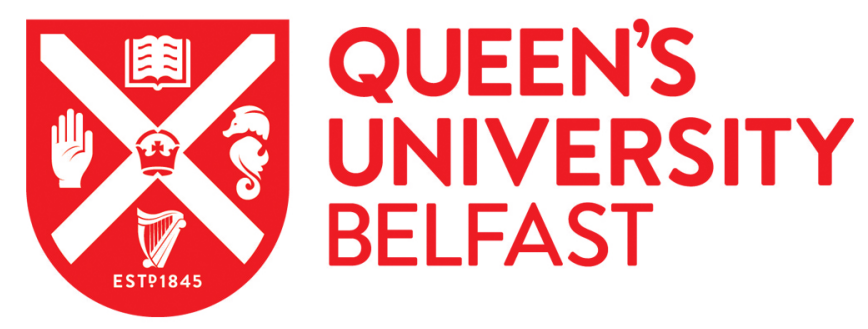

\title{
Mandibular implant-supported fixed complete dental prostheses on implants with ultrashort and standard length: a pilot case based on a new concept
}

Schimmel, M., Janner, S., Joda, T., Wittneben Matter, J., McKenna, G., \& Bragger, U. (2020). Mandibular implant-supported fixed complete dental prostheses on implants with ultrashort and standard length: a pilot case based on a new concept. Journal of Prosthetic Dentistry. https://doi.org/10.1016/j.prosdent.2020.04.013

Published in:

Journal of Prosthetic Dentistry

Document Version:

Peer reviewed version

Queen's University Belfast - Research Portal:

Link to publication record in Queen's University Belfast Research Portal

\section{Publisher rights}

Copyright 2020 Elsevier.

This manuscript is distributed under a Creative Commons Attribution-NonCommercial-NoDerivs License

(https://creativecommons.org/licenses/by-nc-nd/4.0/), which permits distribution and reproduction for non-commercial purposes, provided the author and source are cited.

\section{General rights}

Copyright for the publications made accessible via the Queen's University Belfast Research Portal is retained by the author(s) and / or other copyright owners and it is a condition of accessing these publications that users recognise and abide by the legal requirements associated with these rights.

Take down policy

The Research Portal is Queen's institutional repository that provides access to Queen's research output. Every effort has been made to ensure that content in the Research Portal does not infringe any person's rights, or applicable UK laws. If you discover content in the

Research Portal that you believe breaches copyright or violates any law, please contact openaccess@qub.ac.uk. 


\section{The Journal of Prosthetic Dentistry \\ Mandibular implant-supported fixed complete dental prostheses on implants with ultrashort and standard length: a pilot case based on a new concept --Manuscript Draft--}

\begin{tabular}{|c|c|}
\hline Manuscript Number: & JPD-D-19-00818R4 \\
\hline Keywords: & Edentulous; extra short dental implants; crossarch prostheses; Guided surgery \\
\hline Corresponding Author: & $\begin{array}{l}\text { Martin Schimmel, Prof., Dr. med. dent., MAS Oral Biol } \\
\text { University of Bern } \\
\text { Bern, SWITZERLAND }\end{array}$ \\
\hline \multirow[t]{3}{*}{ Order of Authors: } & Martin Schimmel, Prof., Dr. med. dent., MAS Oral Biol \\
\hline & Simone F Janner, PD Dr. med. dent. \\
\hline & Tim Joda, Prof. Dr. med. Dent., MSc \\
\hline Abstract: & $\begin{array}{l}\text { Edentulous patients may be restored with complete-arch implant-supported fixed } \\
\text { complete dental prostheses (IFCDPs) on angled distal implants or on parallel implants } \\
\text { distributed equally across the mandible to increase the area of support. A treatment is } \\
\text { presented to introduce the clinical concept of providing edentulous patients with an } \\
\text { IFCDP on parallel tissue-level implants in the mandible with standard length implants } \\
\text { interforaminally and ultrashort implants distally. A structured prosthetic approach was } \\
\text { used for the tooth arrangement with a modified workflow according to the Biofunctional } \\
\text { Prosthetic System (BPS) adapted for static computer-aided implant surgery (s-CAIS) } \\
\text { and computer-aided design and computer-aided manufacturing (CAD-CAM) of the } \\
\text { screw-retained IFCDP. The concept offered advantages in challenging anatomical, } \\
\text { surgical, and prosthetic conditions; providing distal nonangled abutments and implant } \\
\text { platforms, which were straightforward to clean. If necessary, the prosthesis could have } \\
\text { been easily converted into a removable overdenture using the existing digital prosthetic } \\
\text { arrangement. Should implant removal be required, the extra short implants can be } \\
\text { removed with minimal surgical risk or morbidity. }\end{array}$ \\
\hline
\end{tabular}


Department of Reconstructive Dentistry and Gerodontology Freiburgstrasse 7, 3010 Bern, Switzerland

Stephen F. Rosenstiel, Columbus, Ohio

Editor-in-Chief, Journal of Prosthetic Dentistry

Columbus, Ohio

Bern, April $17^{\text {th }}, 2020$ $b$

UNIVERSITÄT

\section{BERN}

Medical Facilty

School of Dental Medicine

Department of Reconstructive

Dentistry and Gerodontology

Division of Gerodontology

Revision of manuscript \# JPD-D-19-0818R3: “Mandibular implant-supported fixed complete dental prostheses on implants with ultrashort and standard length: a pilot case based on a new concept"

Dear Editor in Chief, dear Professor Rosenstiel.

Thank you very much for the acceptance of our manuscript, and even more having worked meticulously with the text again.

I accepted all your suggested changes, thank you very much for that.

I hope you and your family are safe and healthy.

Kind regards,

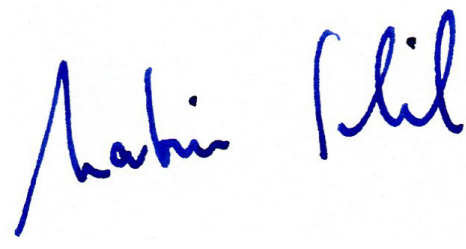

+ swissuniversity.ch
Prof. Dr. med. dent. M. Schimmel


Murtenstrasse 31, 3010 Bern

Präsident:

Prof. Dr. med. Christian Seiler

www.kek-bern.ch

Generalsekretärin:

Dr. sc. nat. Dorothy Pfiffner

Tel.: 0316328633

Fax: 0316328639

Email:pfiffner@kek.unibe.ch

Frau

Dr. Julia Dorn

Group Leader Clinical Research

Institut Straumann AG

Peter-Merian-Weg 12

4052 Basel

Bern, 06. Juli 2016 CS/DP/NR

\section{Basec-Nr.: 2016-00725}

Clinical performance of $4 \mathrm{~mm}$ short distal implants in fixed cross-arch prostheses - an open, randomized, controlled study.

CR 03/15

KlinV, Kat. A

Wir haben die Unterlagen zu nachfolgendem Entscheid am 30.06.2016 über das Basec erhalten.

Sehr geehrte Frau Dr. Dorn

Besten Dank für die Einreichung der obengenannten Unterlagen.

Nach deren inhaltlichen Prüfung halten wir im Namen der KEK fest, dass alle Bedingungen erfüllt worden sind.

Damit kann die KEK Ihnen für das eingangs genannte Forschungsprojekt eine Bewilligung erteilen (ohne Neubegutachtung des gesamten Gesuchs, mit präsidialem Entscheid und mit Information der Gesamtkommission).

\section{Entscheid}

\section{凶Bewilligung}

Gilt für die Zentren:

EK BE, Universität Bern, Dr. med. dent. Julia-Gabriela Wittneben 
Wir machen Sie darauf aufmerksam, dass gegenüber der KEK in folgenden Situationen eine Meldepflicht besteht:

1. Sofern für das Forschungsprojekt eine zusätzliche Pflicht zur Bewilligung durch weitere Behörden (Swissmedic/BAG/BAFU) besteht, müssen die erforderlichen Bewilligungen vor Versuchsbeginn vorliegen.

2. bei schwerwiegenden unerwünschten Ereignissen gemäss Safety Reporting Prozedere (www.swissethics.ch);

3. Änderungen, die sich auf die Sicherheit und Gesundheit der teilnehmenden Personen oder deren Rechte und Pflichten auswirken;

4. Klinische Versuche (KlinV): Änderungen des Prüfplans, namentlich Änderungen aufgrund neuer wissenschaftlicher Erkenntnisse, welche die Versuchsanordnung, die Prüfmethode, die Zielkriterien oder das statistische Auswertungskonzept betreffen;

5. Klinische Versuche (KlinV): Abbruch oder Unterbruch innert 15 Tagen, Abschluss innert 90 Tagen;

6. übrige Projekte (HFV): Abbruch oder Unterbruch innert 90 Tagen;

7. die Änderung des Durchführungsortes oder die Durchführung des klinischen Versuchs an einem zusätzlichen Durchführungsort; oder

8. die Änderung des Sponsors, der koordinierenden Prüfperson oder der an einem Durchführungsort verantworțlichen Prüfperson resp. der Projektleitung

Wir danken Ihnen für Ihre Bemühungen und wünschen für die Studie viel Erfolg.

Freundliche Grüsse

\section{Kantonale Ethikkommission Bern (KEK)}

Bern, 06.07.2016

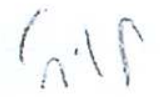

Prof. Dr. med. Christian Seiler

Dr. sc. nat. Dorothy Pfiffner

Präsident

Generalsekretärin

\section{Gebühren: 0.-}


Wir machen Sie darauf aufmerksam, dass:

1. klinische Versuche mit Arzneimitteln, Blut/Blutprodukten, Impfstoffen und Produkten aus dem Bereich der Gentherapie oder Medizinprodukten bei der Swissmedic, dem Schweizerischen Heilmittelinstitut, Hallerstrasse 7, Postfach, 3000 Bern 9, zur Notifikation gemeldet werden müssen.

2. Klinische Studien aus den Bereichen der Transplantate (Organe, Gewebe und Zellen) dem BAG (Bundesamt für Gesundheit) gemeldet werden müssen. Zudem besteht eine Bewilligungspflicht für den grenzüberschreitenden Verkehr mit Transplantaten und eine Bewilligungspflicht für Xenotransplantate (zuständig ist ebenfalls das BAG).

3. klinische Studien mit Radiopharmazeutika, oder mit radioaktiven, oder radioaktiv markierten Substanzen dem BAG, Abt. Strahlenschutz gemeldet werden (Art. 28 oder 29 der Strahlenschutzverordnung (1994, rev. 2005, SR814.501).

\section{Rechtsmittelbelehrung}

Gegen diese Verfügung kann innert 30 Tagen seit Eröffnung bei der Gesundheits- und Fürsorgedirektion des Kantons Bern Beschwerde erhoben werden. Die Beschwerdefrist kann nicht verlängert werden. Die Beschwerdeschrift ist im Doppel der Gesundheits- und Fürsorgedirektion des Kantons Bern, Dienststelle Beschwerden, Rathausgasse 1, 3011 Bern zuzustellen.

Sie muss

(a) angeben, weiche Entscheidung anstelle der angefochtenen Verfügung beantragt wird und

(b) aus welchen Gründen diese andere Entscheidung verlangt wird sowie

(c) die Unterschrift der beschwerdeführenden Partei oder der sie vertretenden Person enthalten.

Der Beschwerdeschrift beizulegen sind die Beweismittel, soweit sie greifbar sind, und die angefochtene Verfügung. Die beschwerdeführende Partei wird bei Unterliegen grundsätzlich kostenpflichtig.

(Artikel 67 in Verbindung mit Art. 32 und Art. 108 Verwaltungsrechtspflegegesetz).

Stand August 2003 
JPD-D-19-00818R3

Comments by the editor

Please download and review the edited manuscript to ensure that your meaning has not been inadvertently altered.

Dear Dr. Rosenstiel

I think your changes greatly improved the text, and I accepted them all.

Kind regards

The authors 
Mandibular implant-supported fixed complete dental prostheses on implants with ultrashort and standard length: a pilot case based on a new concept

Martin Schimmel, PD, Dr med dent, ${ }^{\mathrm{a}}$ Simone FM Janner, PD, Dr med dent, ${ }^{\mathrm{b}}$ Tim Joda, PD, Dr med dent, ${ }^{\mathrm{c}}$ Julia G. Wittneben, PD, Dr med dent, MMSc, ${ }^{\mathrm{d}}$ Gerald McKenna, PhD,${ }^{\mathrm{e}}$ and Urs Brägger, PD, Dr med dent ${ }^{\mathrm{f}}$

${ }^{a}$ Full Professor, Department of Reconstructive Dentistry and Gerodontology, School of Dental Medicine, University of Bern, Bern, Switzerland.

${ }^{\mathrm{b}}$ Senior Lecturer, Department of Oral Surgery and Stomatology, School of Dental Medicine, University of Bern, Bern, Switzerland.

${ }^{c}$ Associate Professor, Department of Reconstructive Dentistry, University Center for Dental Medicine, Basel, Switzerland.

${ }^{\mathrm{d}}$ Senior Lecturer, Department of Reconstructive Dentistry and Gerodontology, School of Dental Medicine, University of Bern, Bern, Switzerland.

${ }^{\mathrm{e} S}$ Senior Lecturer, Centre for Public Health, Queens University Belfast, Institute of Clinical Sciences Block B, Belfast, United Kingdom.

${ }_{\mathrm{f}}^{\mathrm{f}}$ Full Professor, Department of Reconstructive Dentistry and Gerodontology, School of Dental Medicine, University of Bern, Bern, Switzerland.

Corresponding author:

Martin Schimmel

University of Bern, School of Dental Medicine 
Department of Reconstructive Dentistry and Gerodontology

Freiburgstrasse 7, 3010 Bern

SWITZERLAND

Email: martin.schimmel@zmk.unibe.ch

Acknowledgments

The authors declare no conflict of interest. All laboratory work was performed by Patrick

Zimmermann (Zahnmanufaktur, Bern, Switzerland). Institut Straumann (Basel, Switzerland)

provided the framework of the prosthesis free of charge. 
JPD-19-818

\title{
CLINICAL REPORT
}

Mandibular implant-supported fixed complete dental prostheses on implants with ultrashort and standard length: A pilot treatment

\begin{abstract}
Edentulous patients may be restored with complete-arch implant-supported fixed complete dental prostheses (IFCDPs) on angled distal implants or on parallel implants distributed equally across the mandible to increase the area of support. A treatment is presented to introduce the clinical concept of providing edentulous patients with an IFCDP on parallel tissue-level implants in the mandible with standard length implants interforaminally and ultrashort implants distally. A structured prosthetic approach was used for the tooth arrangement with a modified workflow according to the Biofunctional Prosthetic System (BPS) adapted for static computer-aided implant surgery (s-CAIS) and computer-aided design and computer-aided manufacturing (CADCAM) of the screw-retained IFCDP. The concept offered advantages in challenging anatomical, surgical, and prosthetic conditions; providing distal nonangled abutments and implant platforms, which were straightforward to clean. If necessary, the prosthesis could have been easily converted into a removable overdenture using the existing digital prosthetic arrangement. Should implant removal be required, the extra short implants can be removed with minimal surgical risk or morbidity.
\end{abstract}

\section{INTRODUCTION}

Rehabilitating edentulous patients remains a necessary and challenging situation, ${ }^{1}$ with a 
prosthetic rehabilitation needed for many elderly and fragile patients, since patients retain their teeth for a longer time and do not require treatment until late in life. ${ }^{2,3}$ Complete-arch implantsupported fixed complete dental prostheses (IFCDPs) were originally developed for rehabilitating edentulous patients with poor function and for increased patient comfort. ${ }^{4,5}$ Typically, 4 to 5 implants had been placed in the interforaminal area and restored with a cantilever extension design while maxillary complete dentures were used in the opposing arch. ${ }^{6}$ Biomechanically, a screw-retained cross-arch fixed prosthesis could benefit from a wide distribution of the implants within the bony arch. One approach to reach a more distal zone with the implant platforms was the concept of using tilted implants still anchored in the interforaminal region. An angled platform would reestablish a regular path of insertion for the fixation of the prosthesis. ${ }^{7}$ Applying another less invasive approach follows the recent trend of using short implants. ${ }^{8}$ The option of ultrashort implants (with a microrough portion of less than $6 \mathrm{~mm}$, terminology according to the European Association of Dental Implantologists ${ }^{9}$ ) has also been described for selected indications, with up to 2 distal ultrashort implants per side to increase total implant-bone contact area. ${ }^{8,9}$ The reasoning is that the increase in the number of posterior implants might be associated with lower marginal bone loss compared with fewer implants. ${ }^{10}$

The purpose of this clinical report was to introduce the concept of providing edentulous patients with an IFCDP supported by parallel tissue-level implants in the mandible with standard length implants interforaminally and ultrashort implants distally. A modified prosthetic approach was used for the tooth arrangement, adapted for static computer-aided implant surgery (s-CAIS) and computer-aided design and computer-aided manufacturing (CAD-CAM) of the screwretained IFCDP fabricated by the dental laboratory technician. 


\section{CLINICAL REPORT}

A 65-year- old woman had been edentulous for 12 months and had been treated with mucosasupported complete dentures. Her chief complaint was the inability to masticate comfortably because of her loose mandibular denture. She requested an IFCDP and new complete maxillary denture. She reported smoking 10 cigarettes a day but was otherwise healthy and not taking any medication. Initial prosthodontic and radiographic screening revealed favorable conditions for an implant-supported prosthesis (Fig. 1).

A preliminary alginate impression (Blueprint; Dentsply Sirona) using a Schreinemaker tray (Clan Dental B.V.) was made at the first clinical appointment. During the second appointment, custom trays with mounted wax rims were adapted, following esthetic parameters, to the bipupilar and Camper planes, and the vertical dimension of occlusion was measured. These custom trays were then used to make closed-mouth definitive impressions with polyvinyl siloxane (Virtual; Ivoclar Vivadent AG). Subsequently, a Gerber Set No. 100 (Gerber Condylator $\mathrm{GmbH}$ ) was mounted chairside on the wax rims and used to record the vertical and horizontal dimensions using the central bearing point technique and gothic arch tracing (Fig. 2). The dental technician assisted in selecting the tooth type and shade (Physiostar NFC+, shade M3. Form 552; Candulor AG).

The tooth arrangement was evaluated clinically while controlling the vertical and horizontal dimensions, and an evaluation of esthetic and functional parameters was performed. A bilaterally balanced occlusion was implemented. Subsequently, both dentures were finished and duplicated in clear resin (Aesthetic Blue; Candulor AG). The mandibular duplicate denture was modified with gutta percha points (WaveOne Gold; Dentsply Sirona) (Fig. 3) to serve as a radiological guide (Fig. 3). 
A cone beam computed tomography (CBCT) image (J. Morita Corp) was obtained with the radiological guide seated. The gathered Digital Imaging and Communications in Medicine (DICOM) data and 2 sets of optical surface scans of the model (with and without the prosthetic arrangement, standard tessellation language [STL] files 1 and 2) were used for virtual implant treatment planning (coDiagnostiX; Dental Wings) (Fig. 4). The 6 planned implants were aligned for insertion direction, favorable access for transocclusal screw retention, depth - maintaining a safe distance from nerve structures, and 1- to 1.5-mm subcrestal distance to the microrough implant surface. An additional millimeter of depth was included wherever anatomically possible to provide flexibility while inserting the parallel-walled implants. Three fixation pins were additionally planned in positions not interfering with the implants. After defining the 3D coordinates of the implant platform, a mucosa- supported drill guide (Objet Eden 260 Connex 2; Stratasys) was printed for fully guided implant surgery, following the corresponding softwaregenerated surgical protocol.

During implant surgery, the surgical guide was first fixed by using 3 transmucosally inserted fixation pins with a 1.5-mm diameter (Guided Anchor Pin; Nobel Biocare) (Fig. 5). After minimal flap elevation in the crestal area to enable ridge levelling where indicated, implant osteotomies were performed according to the previously specified s-CAIS protocol. Correct positioning of the osteotomies was clinically verified by using the radiological guide during the surgery after temporarily removal of the drill guide. Two standard length, regular neck (RN), tissue-level implants (Straumann Standard (S), diameter $4.1 \mathrm{~mm}, 12 \mathrm{~mm}$ length; Institut Straumann AG) were positioned in the regions of the mandibular right and left canines. Four ultrashort tissue-level implants (Straumann Standard Plus (SP), RN, diameter $4.1 \mathrm{~mm}, 4 \mathrm{~mm}$ length, Institut Straumann AG) were inserted in the regions of the mandibular right and left 
second premolars and first molars. All implants featured hydrophilic, airborne-particle abraded, acid-etched, and microroughened surfaces (SLActive; Institut Straumann AG). Healing abutments with a height of $3 \mathrm{~mm}$ were applied for transmucosal healing. To enable a nonloaded healing period, all areas of the intaglio surface of the denture that might have contacted the healing abutments were relieved. After an uneventful 10-week healing period, implant osseointegration was assessed clinically, radiologically (Fig. 6), and by using the implant stability quotient scale (ISQ; Osstell) before the prosthetic phase.

An alginate impression (Blueprint; Dentsply Sirona) was made with impression posts (RN Impression Post for open-tray impression, $11 \mathrm{~mm}$ in height, Institut Straumann AG) in place. On the resulting stone cast (dental klasse 4 primus; Klasse 4 dental $\mathrm{GmbH}$ ), the radiological guide was modified with recesses for the impression trays to serve as a "transmission" guide. The definitive open-tray impression was obtained in centric occlusion with the duplicate of the maxillary denture in place (Fig. 7). This step simultaneously transferred both the position of the implant platform relative to the position of the teeth and the vertical and horizontal dimensions of occlusion. Additionally, an alginate impression (Blueprint; Dentsply Sirona) of the maxillary denture was made, and a registration of the vertical and horizontal dimension of occlusion with the denture in place was recorded by using a silicone impression material (Exabite II, GC Europe) to monitor possible changes in the maxillary denture during the healing period.

The framework was subsequently designed using a software program (Straumann CARES Scan \& Shape; Institut Straumann AG) and milled from a cobalt- chromium alloy (coron; etkon Straumann) to achieve high mechanical resistance and reliable bond strength of the denture base material to the framework. ${ }^{11}$ Corrections to the tooth axes, occlusion, and access for 
cleaning with interdental brushes and floss were implemented at the clinical evaluation. The correct marginal fit of the framework on the implant platforms was verified radiographically. The definitive fixed, screw-retained, cross- arch prosthesis was delivered at the second appointment following definitive impression-making with the "transmission" guide. The existing maxillary denture remained unchanged. The occlusal pattern was a bilaterally balanced occlusion replicated from the initial tooth arrangement (Fig. 8). The patient was satisfied with the prostheses.

At the 1-year follow-up visit, radiographic and clinical parameters indicated stable tissue conditions. The prosthesis was intact and well-cleaned. Spatial access for oral hygiene measures had been a prerequisite during the design of the prosthesis. The patient showed a high level of satisfaction with and full adaptation to the prosthetic rehabilitation.

At two and a half years after delivery of the IFCDP, the patient was reexamined clinically and radiologically. She had been able to maintain a high level of plaque control and denture hygiene, even at the intaglio surfaces in the distal areas of the prosthesis. After removal of the screw-retained prosthesis during this recall appointment, minimal plaque was observed. At the implant-platform connection regions, the framework was nearly plaque-free. Clinical signs of inflammation were minimal, except for the lingual aspect of the implant in the mandibular left canine region. There, only a shallow band of keratinized mucosa was present. No probing pocket depth (PPD) greater than $4 \mathrm{~mm}$ was noted. Injury from interdental brushes was observed.

Radiographic evaluation showed stable peri-implant bone levels (Fig. 9). The patient reported full satisfaction with the prosthetic rehabilitation, had ceased smoking, and had gained some weight. 


\section{DISCUSSION}

Promising concepts for optimizing patient comfort by combining a minimally invasive surgical approach with a fixed implant- supported reconstruction are underrepresented in the literature. The provision of 10 edentulous patients with a cross-arch fixed prosthesis has been described in a recent case series. ${ }^{10}$ Two $10-\mathrm{mm} \mathrm{RN}$ - implants were inserted in the anterior area of the mandible and then splinted to 4 extra-short RN implants (4-mm endosseous length) in the posterior area of the mandible. The authors did not report on 3D planning or a minimally invasive approach with guided surgery. Of the 40 extra-short implants, 1 was lost after the 2month healing period but successfully replaced 2 weeks later. During the 12 months of observation, the extra-short implants demonstrated similar clinical and radiographic results relative to the $10-\mathrm{mm}$ implants. Prosthetic procedures were scheduled to commence 10 to 12 weeks after implant placement and were implemented only after all implants had shown ISQ values greater than or equal to $70 . .^{8}$

Providing edentulous patients with an IFCDP is a clinical challenge, especially if the mandible shows signs of atrophy of the alveolar crest. In this indication, a fully guided approach seems advantageous for placing ultrashort implants, as there is only a small margin of error. Furthermore, immediate loading of ultrashort implants may constitute a higher risk for early loss than standard loading protocols. The more conservative approach, therefore, prolongs the temporization period and negatively affects patient comfort. Compared with the use of tilted distal implants to support an IFCDP, the current approach offers several advantages. First, the use of straight, ultrashort implants in the posterior mandible provides an arrangement that may be as easy to maintain and clean as tilted implants but avoids specially designed multi- angle abutments. The soft tissue-level design of the implants may further promote the health of the 
peri-implant tissues. ${ }^{12}$ Second, by combining distal support with 2 ultrashort implants, a cantilever extension is avoided. This may reduce the risk of technical complications. Third, edentulous patients tend to be elderly and may experience an onset of frailty and/or care dependence. ${ }^{13}$ In such situations, an existing IFCDP can easily be transformed into a removable prosthesis to allow for easier handling and cleaning. A removable version of the fixed prosthesis could readily be manufactured using the existing digital dataset of the prosthetic arrangement. Finally, if a posterior implant requires removal, the ultrashort implants can be removed with low morbidity and surgical risk, fulfilling the requirements of a back-off strategy. ${ }^{14}$

\section{SUMMARY}

The described treatment approach demonstrated the clinical feasibility of providing atrophied mandibles with IFCDPs supported by a combination of anterior regular and distal ultrashort tissue-level implants. This approach combined the advantages of a simplified prosthetic treatment concept: virtual prosthetic and surgical planning, s-CAIS, and novel CAD-CAMsupported complete-arch reconstruction. Thus, it may offer improvements when dealing with challenging anatomical, surgical, and prosthetic conditions within a reasonable financial budget. 


\section{REFERENCES}

1. Felton DA. Edentulism and comorbid factors. J Prosthodont 2009;18:88-96.

2. Ducommun J, El Kholy K, Rahman L, Schimmel M, Chappuis V, Buser D. Analysis of trends in implant therapy at a surgical specialty clinic: Patient pool, indications, surgical procedures, and rate of early failures-A 15-year retrospective analysis. Clin Oral Implants Res 2019;30:1097106.

3. Slade GD, Akinkugbe AA, Sanders AE. Projections of U.S. Edentulism prevalence following 5 decades of decline. J Dent Res 2014;93:959-65.

4. Adell R, Lekholm U, Rockler B, Branemark PI. A 15-year study of osseointegrated implants in the treatment of the edentulous jaw. Int J Oral Surg 1981;10:387-416.

5. Branemark PI, Hansson BO, Adell R, Breine U, Lindstrom J, Hallen O, et al. Osseointegrated implants in the treatment of the edentulous jaw. Experience from a 10-year period. Scand J Plast Reconstr Surg Suppl 1977;16:1-132.

6. Lundgren D, Falk H, Laurell L. Influence of number and distribution of occlusal cantilever contacts on closing and chewing forces in dentitions with implant-supported fixed prostheses occluding with complete dentures. Int J Oral Maxillofac Implants 1989;4:277-83.

7. Maló P, de Araújo Nobre M, Lopes A, Ferro A, Botto J. The All-on-4 treatment concept for the rehabilitation of the completely edentulous mandible: A longitudinal study with 10 to 18 years of follow-up. Clin Implant Dent Relat Res 2019;21:565-77.

8. Calvo-Guirado JL, Lopez Torres JA, Dard M, Javed F, Perez-Albacete Martinez C, Mate Sanchez de Val JE. Evaluation of extrashort 4-mm implants in mandibular edentulous patients with reduced bone height in comparison with standard implants: a 12-month results. Clin Oral Implants Res 2016;27:867-74. 
9. Falisi G, Bernardi S, Rastelli C, Pietropaoli D, F DEA, Frascaria M et al. "All on short" prosthetic-implant supported rehabilitations. Oral Implantol (Rome) 2017;10:477-87.

10. Tabrizi R, Arabion H, Aliabadi E, Hasanzadeh F. Does increasing the number of short implants reduce marginal bone loss in the posterior mandible? A prospective study. Br J Oral Maxillofac Surg 2016;54:731-5.

11. Matsuda Y, Yanagida H, Ide T, Matsumura H, Tanoue N. Bond strength of poly(methyl methacrylate) denture base material to cast titanium and cobalt-chromium alloy. J Adhes Dent 2010;12:223-9.

12. Derks J, Schaller D, Hakansson J, Wennstrom JL, Tomasi C, Berglundh T. Effectiveness of implant therapy analyzed in a Swedish population: prevalence of peri-implantitis. J Dent Res 2016;95:43-9.

13. Müller F, Schimmel M. Revised success criteria: a vision to meet frailty and dependency in implant patients. Int J Oral Maxillofac Implants 2016;31:15.

14. Schimmel M, Müller F, Suter V, Buser D. Implants for elderly patients. Periodontol 2000 2017;73:228-40. 


\section{FIGURES}

Figure 1. Sixty-five-year- old woman reported insufficient comfort with her complete dentures. A, Edentulous maxilla. B, Edentulous ridge in mandible. C, Dentures at outset of treatment.

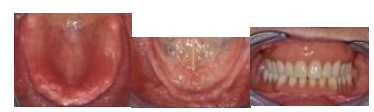

Figure 2. A, Closed-mouth impressions with special trays using Virtual. B, Custom trays used for registration of vertical and horizontal occlusal dimensions. C, Posterior view of registration block. All necessary information for designing tooth arrangement recorded: denture-bearing mucosa, esthetic parameters, orientation of occlusal plane, vertical and horizontal occlusal dimensions.

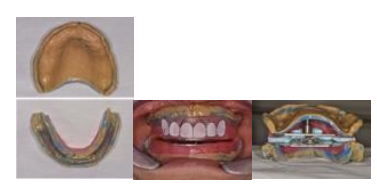

Figure 3. A, Finished maxillary denture in place. B, Duplicates of dentures with radio-opaque references to serve as radiological guide

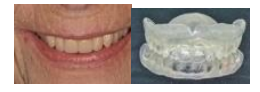

Figure 4. Virtual implant planning based on scanned mandibular cast with and without denture and superimposition with CBCT data (coDiagnostiX). A, Superimposition of 3D data and visualization of tooth arrangement and implant positions. B, Surgical guide planning. CBCT, cone beam computed tomography.

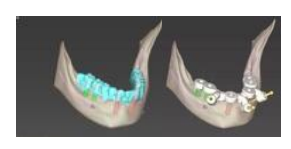

Figure 5. Surgical guide in place with fixation pins.

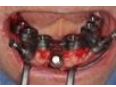


Figure 6. Control CBCT scan made after 10-week healing period to verify correct 3D implant positions. CBCT, cone beam computed tomography.

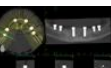

Figure 7. A, Radiological guide modified into transmission guide, which served as individual impression tray. In combination with completed maxillary denture, centric occlusion could be defined in same session. B, Intaglio impression surface.

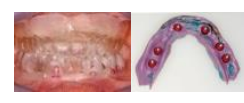

Figure 8. Final prosthesis in place. Parallel position of implants allowed for screw retention using framework without additional multiunit abutments.

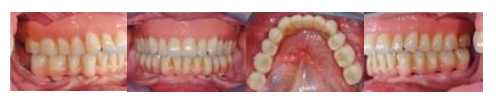

Figure 9. Follow-up after 31 months.

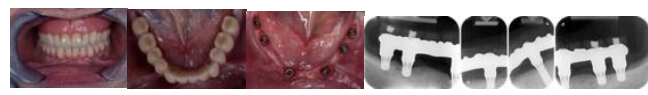




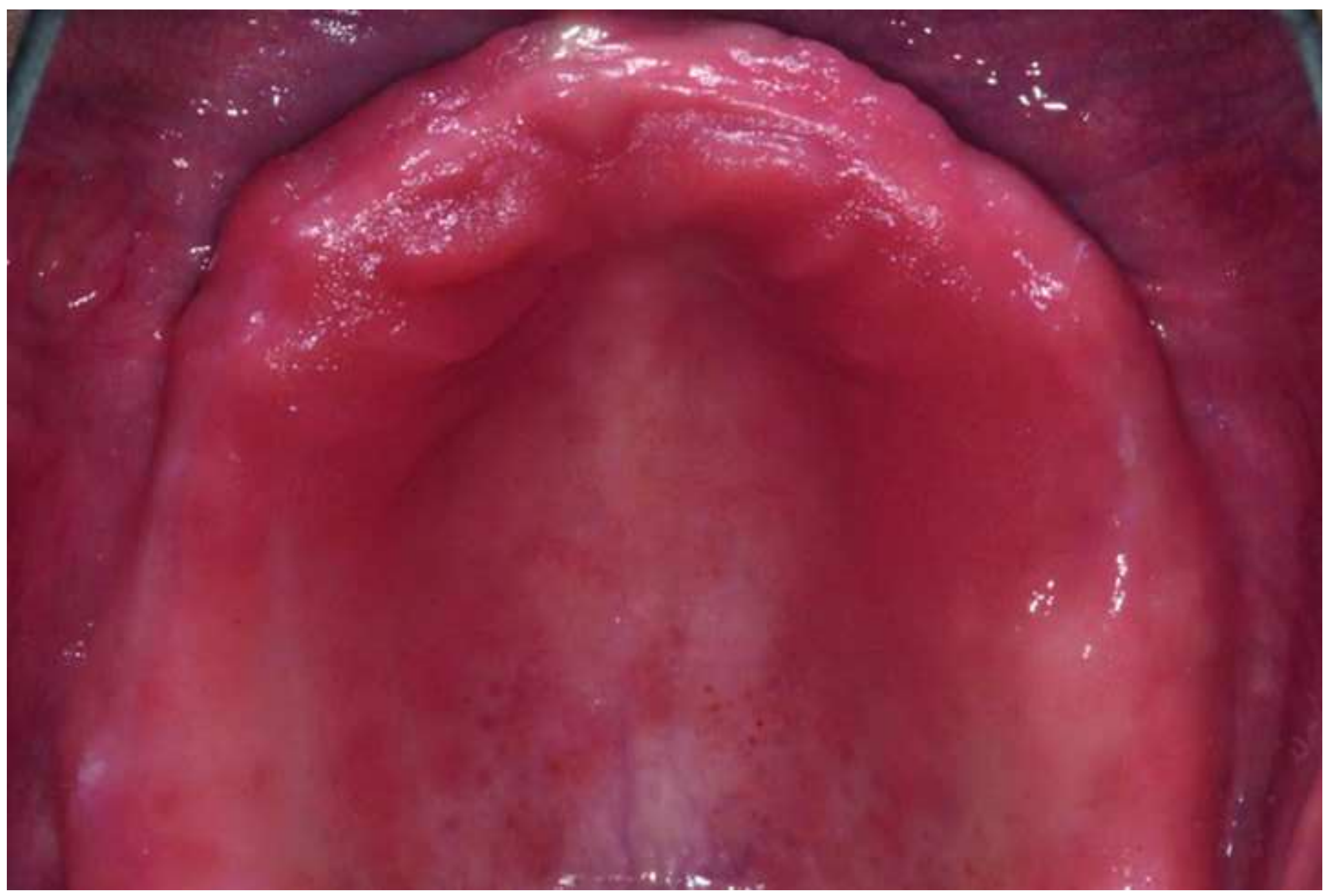

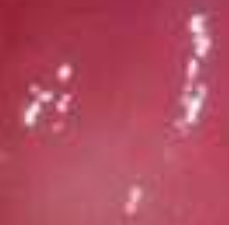




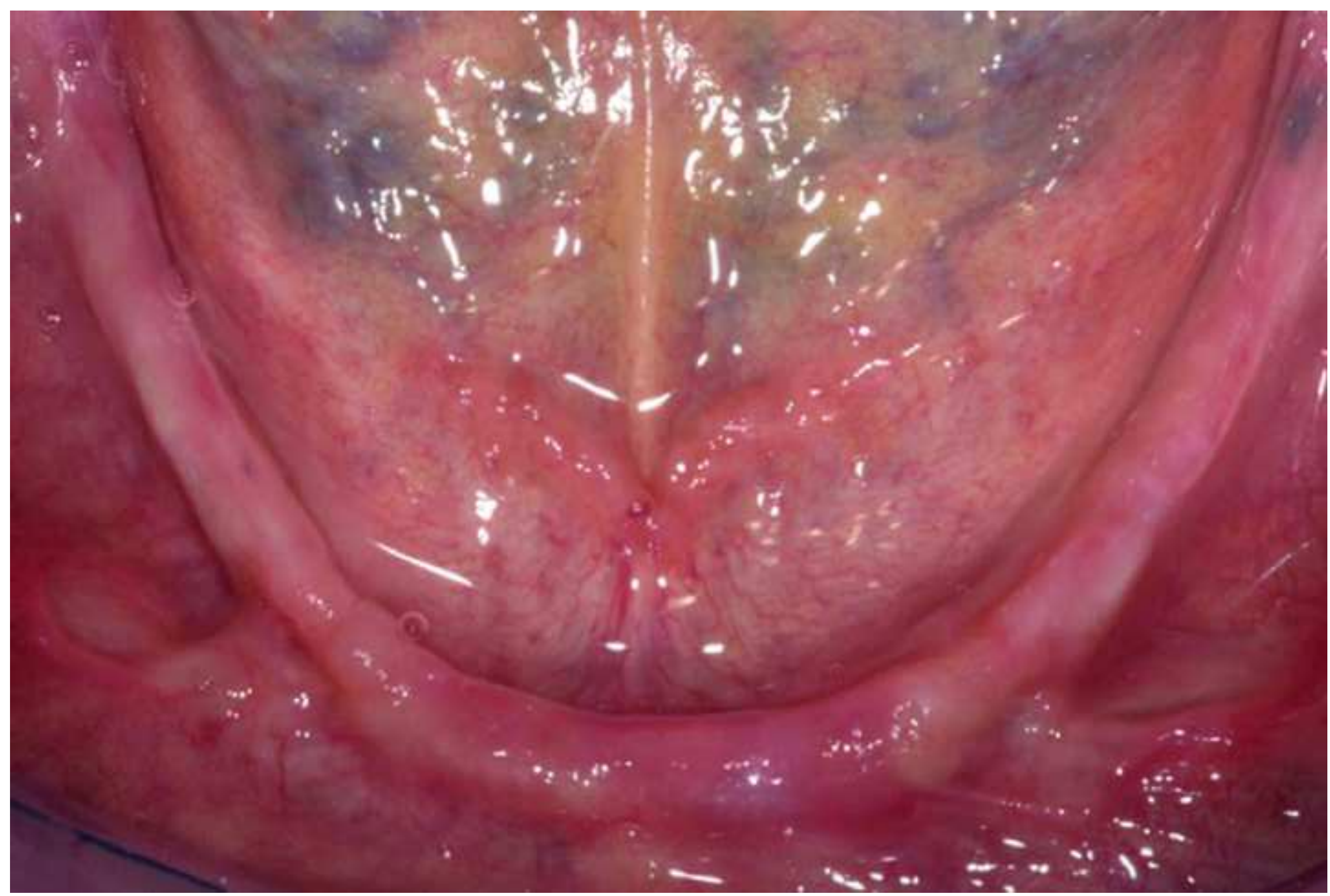



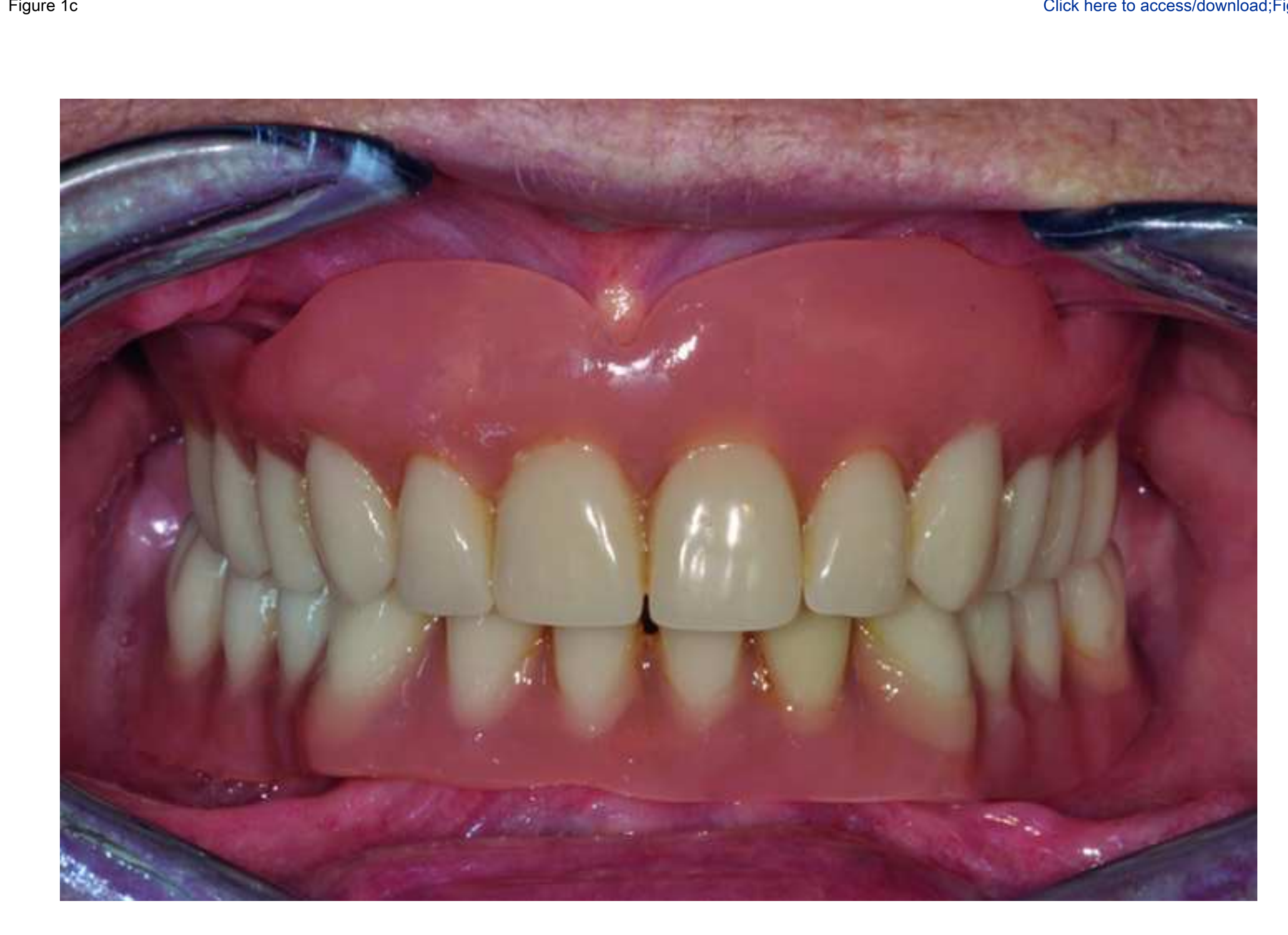


$$
\text { (5) }
$$




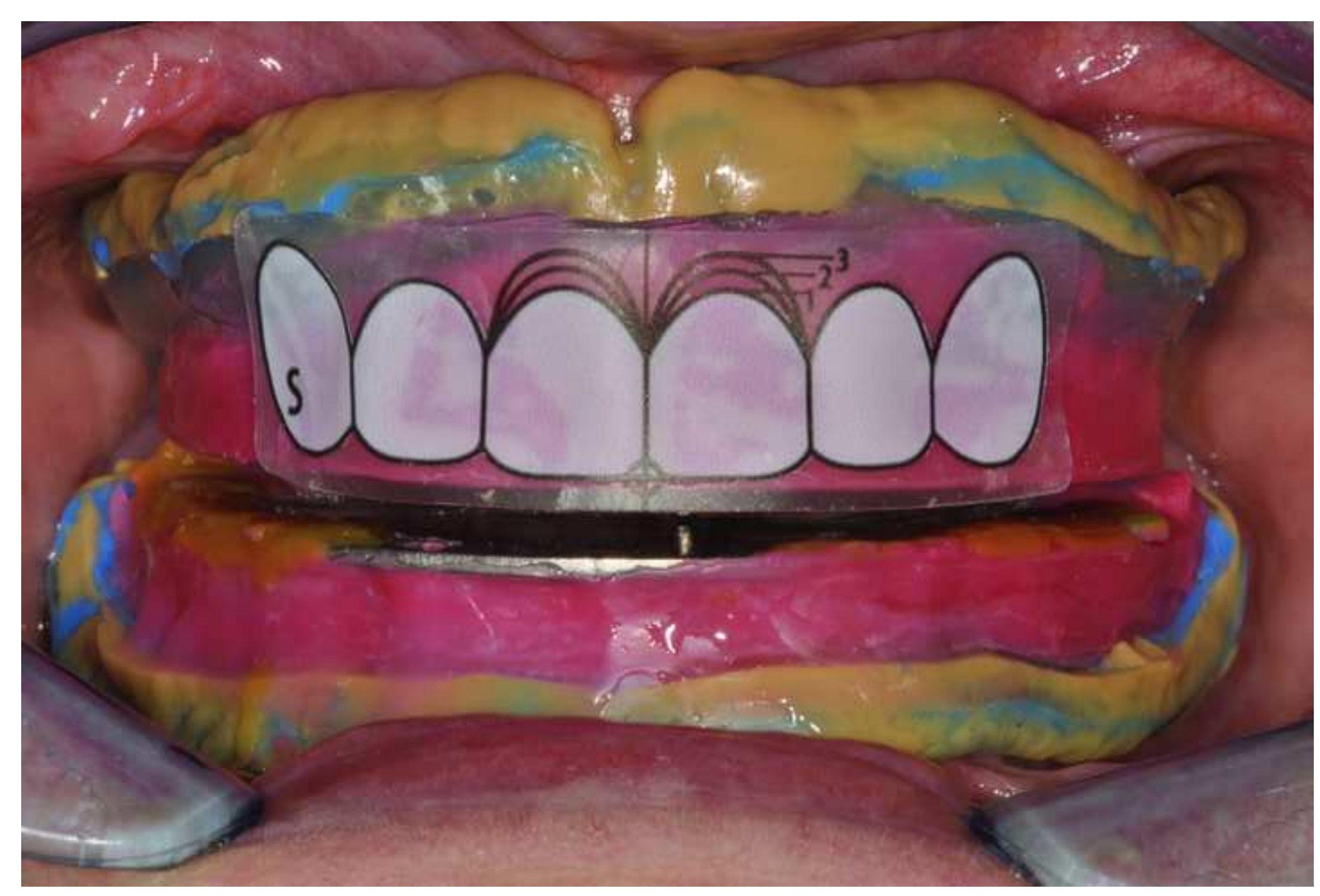



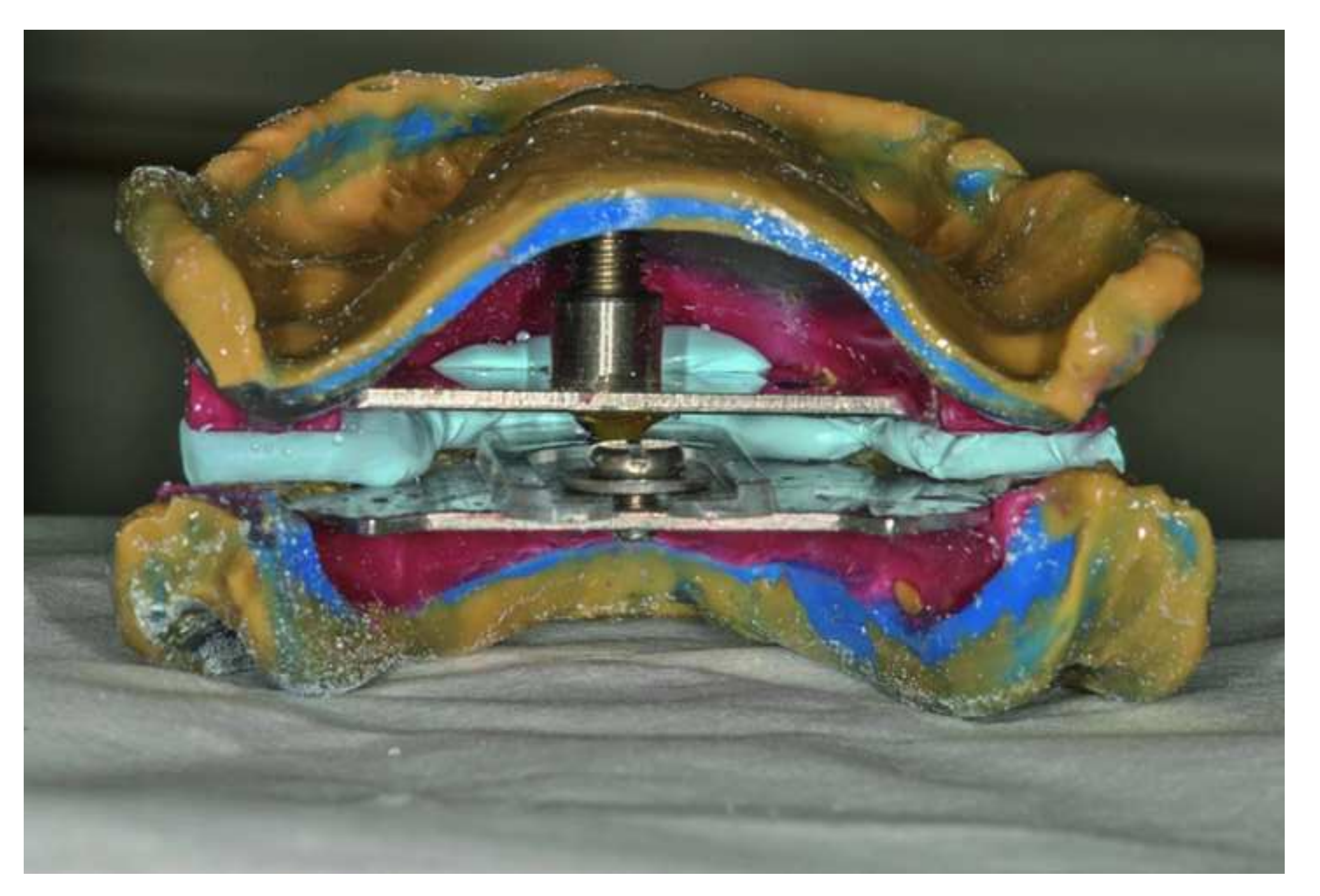

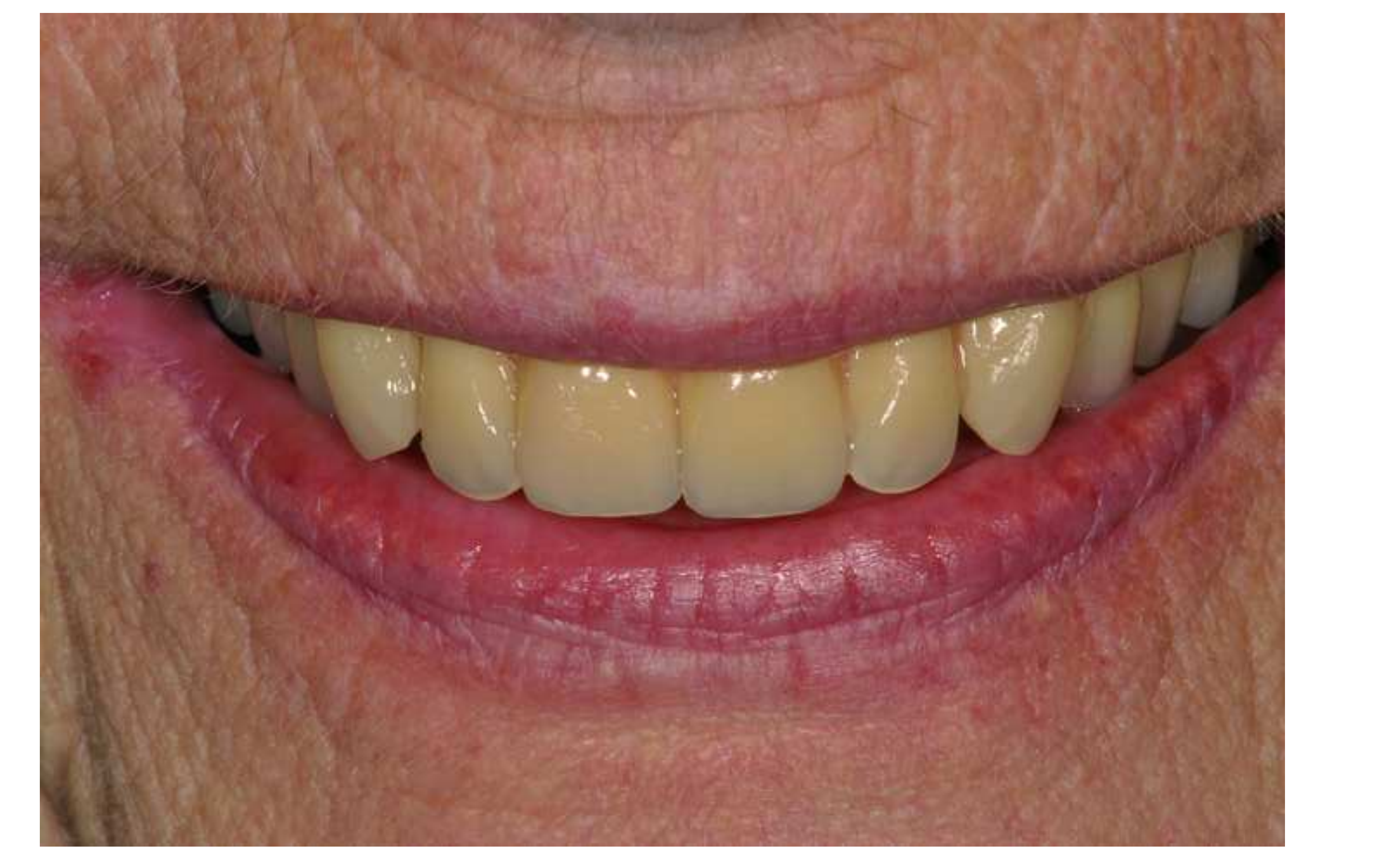

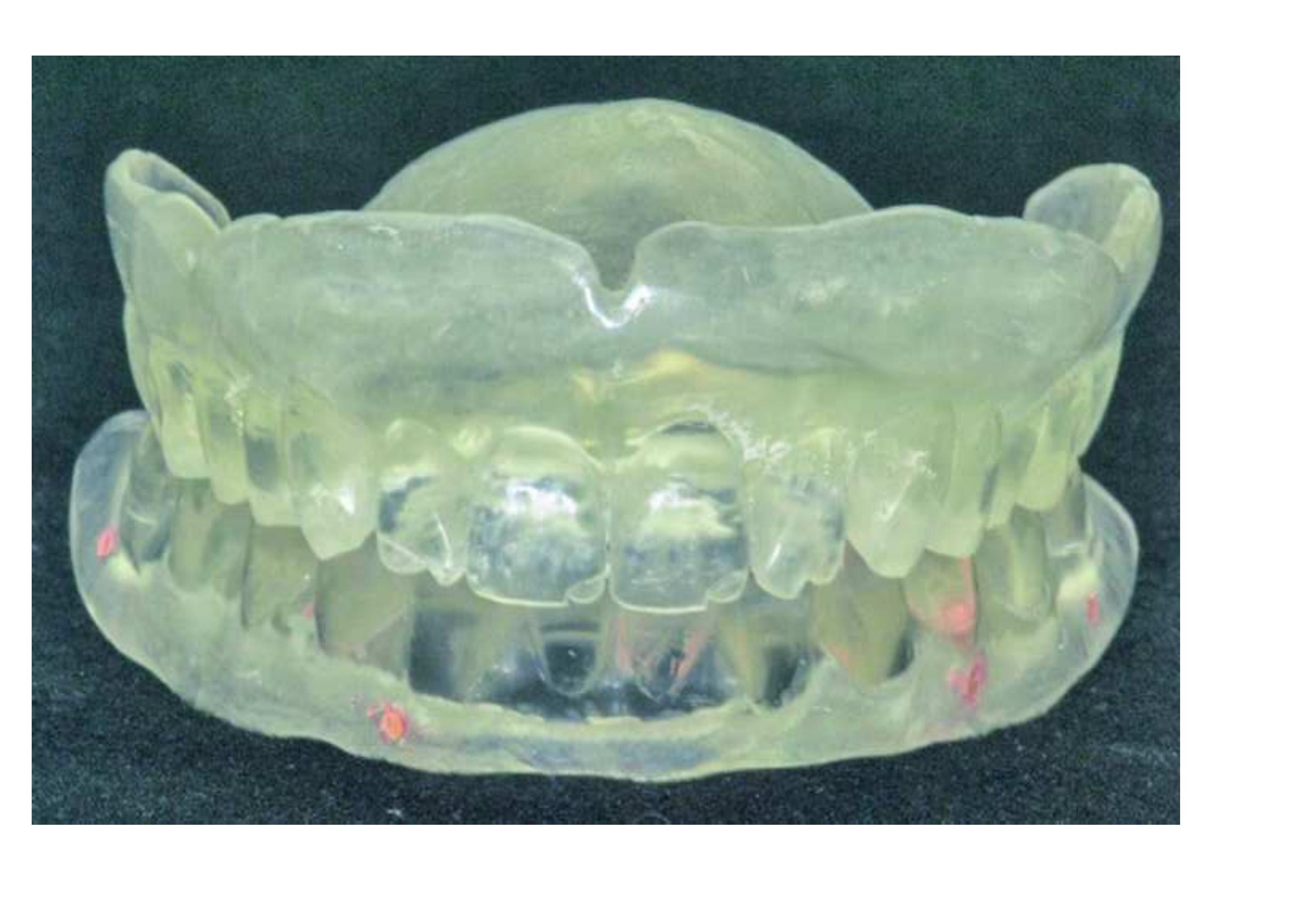

Figure

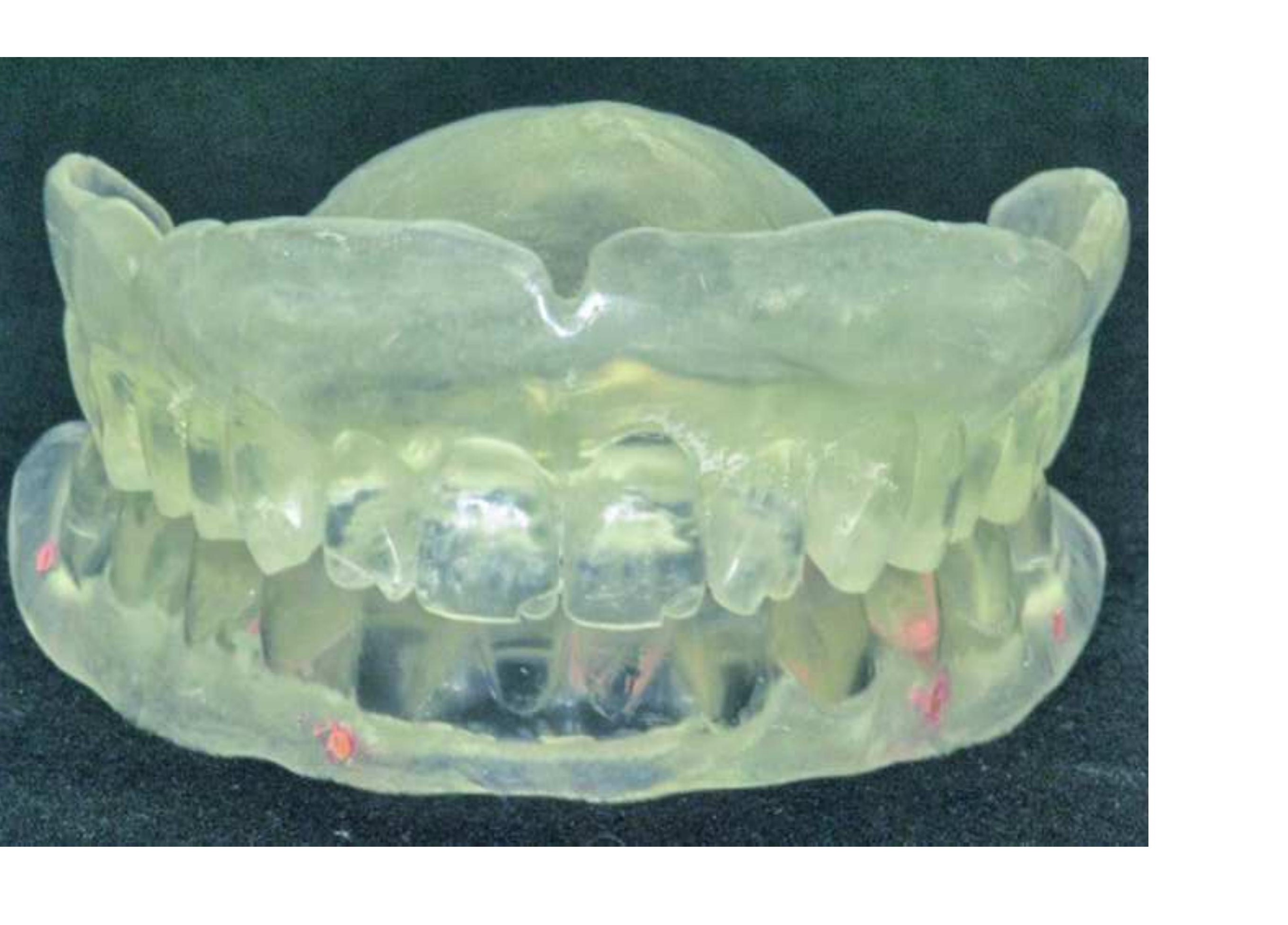




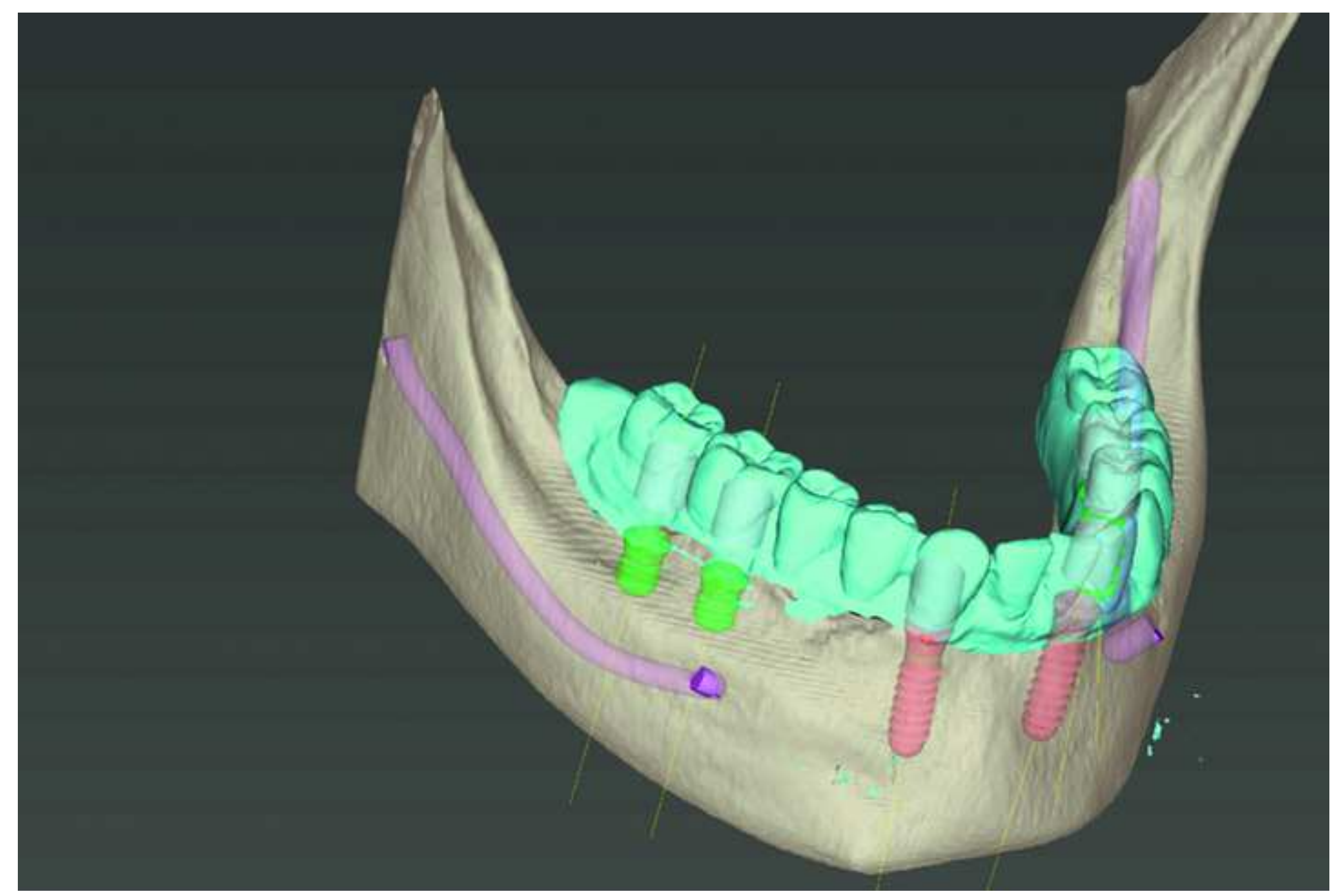


Click here to access/download;Figure;4b.tif $\underline{\underline{ }}$

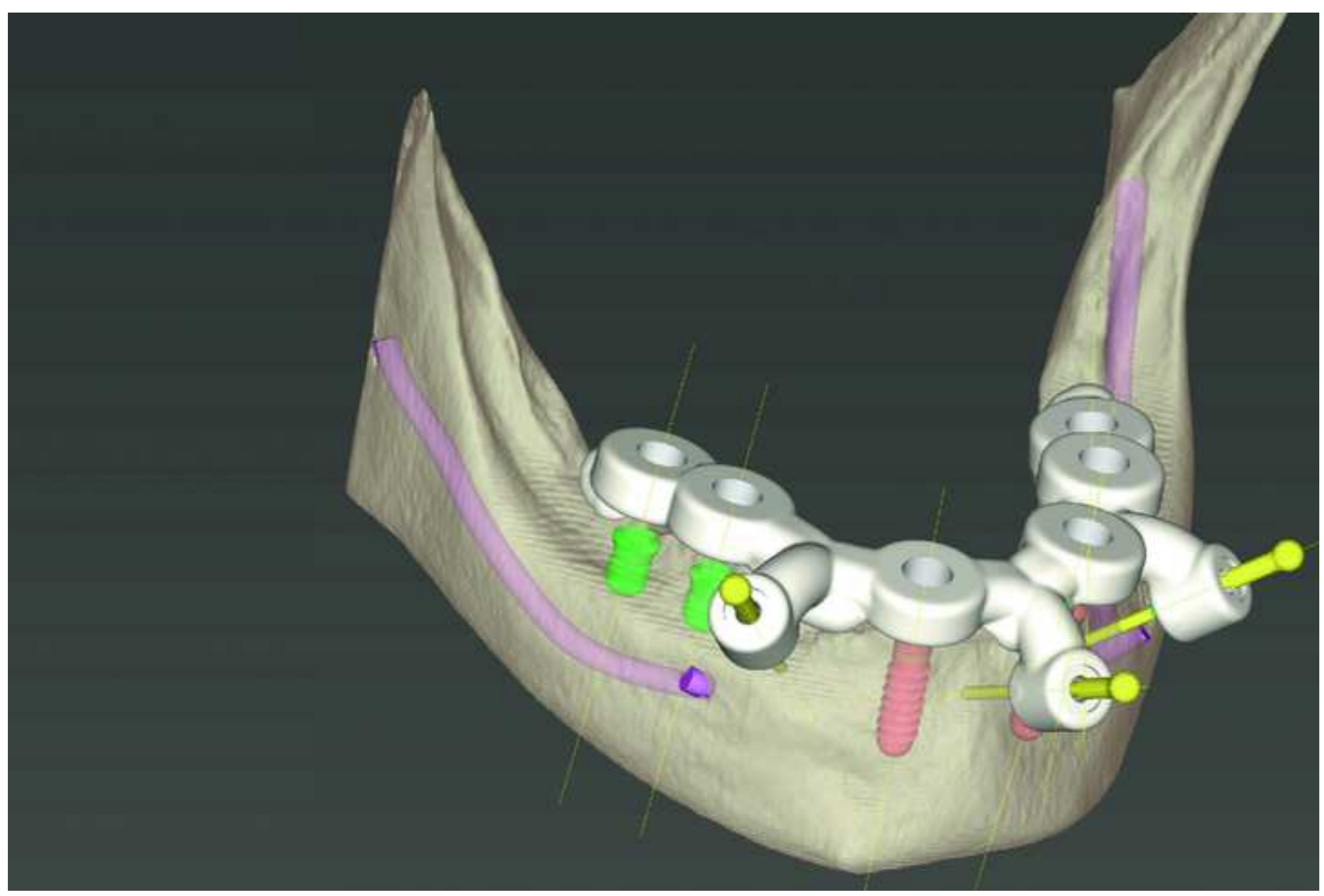




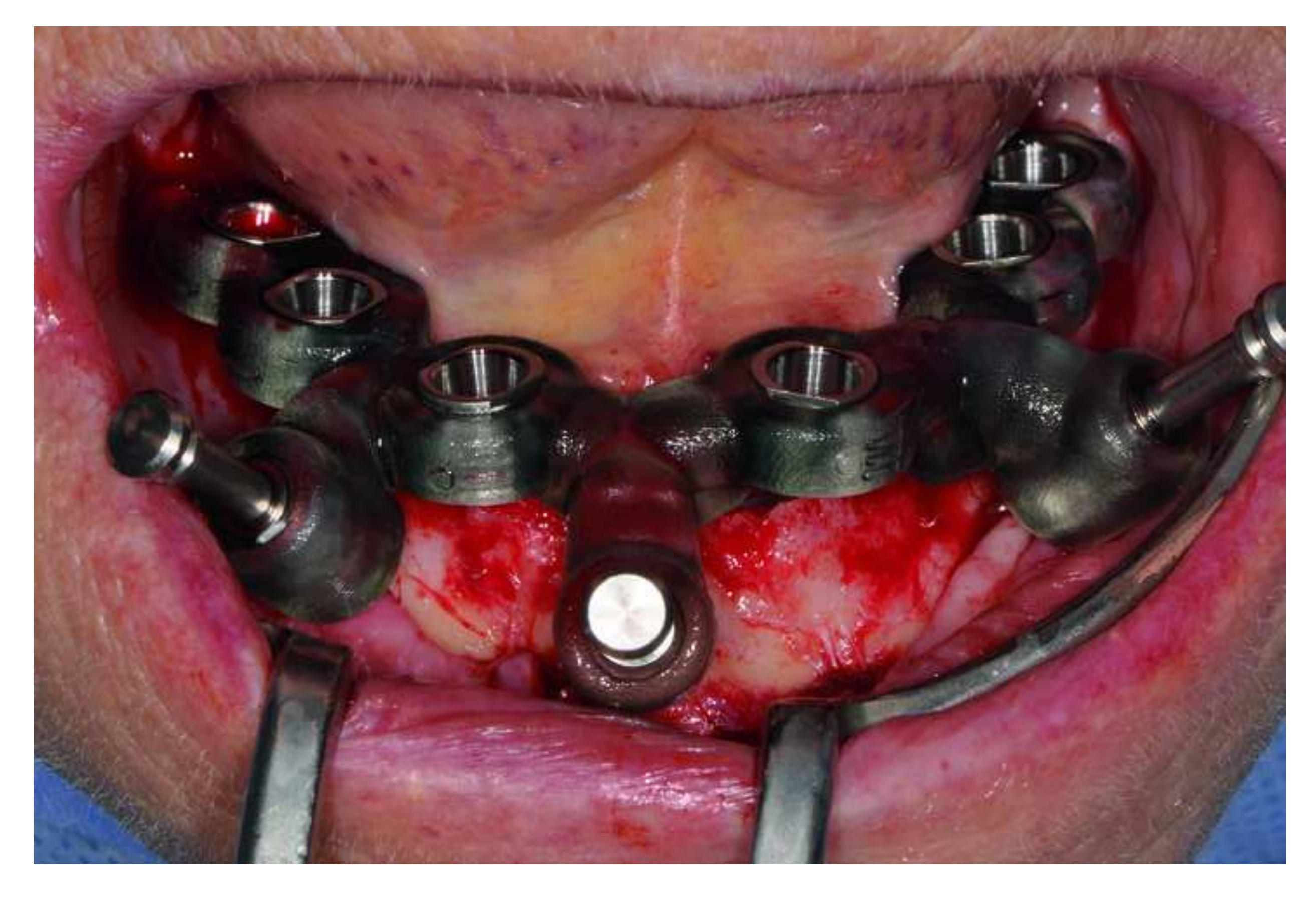

AE

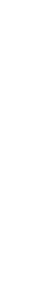
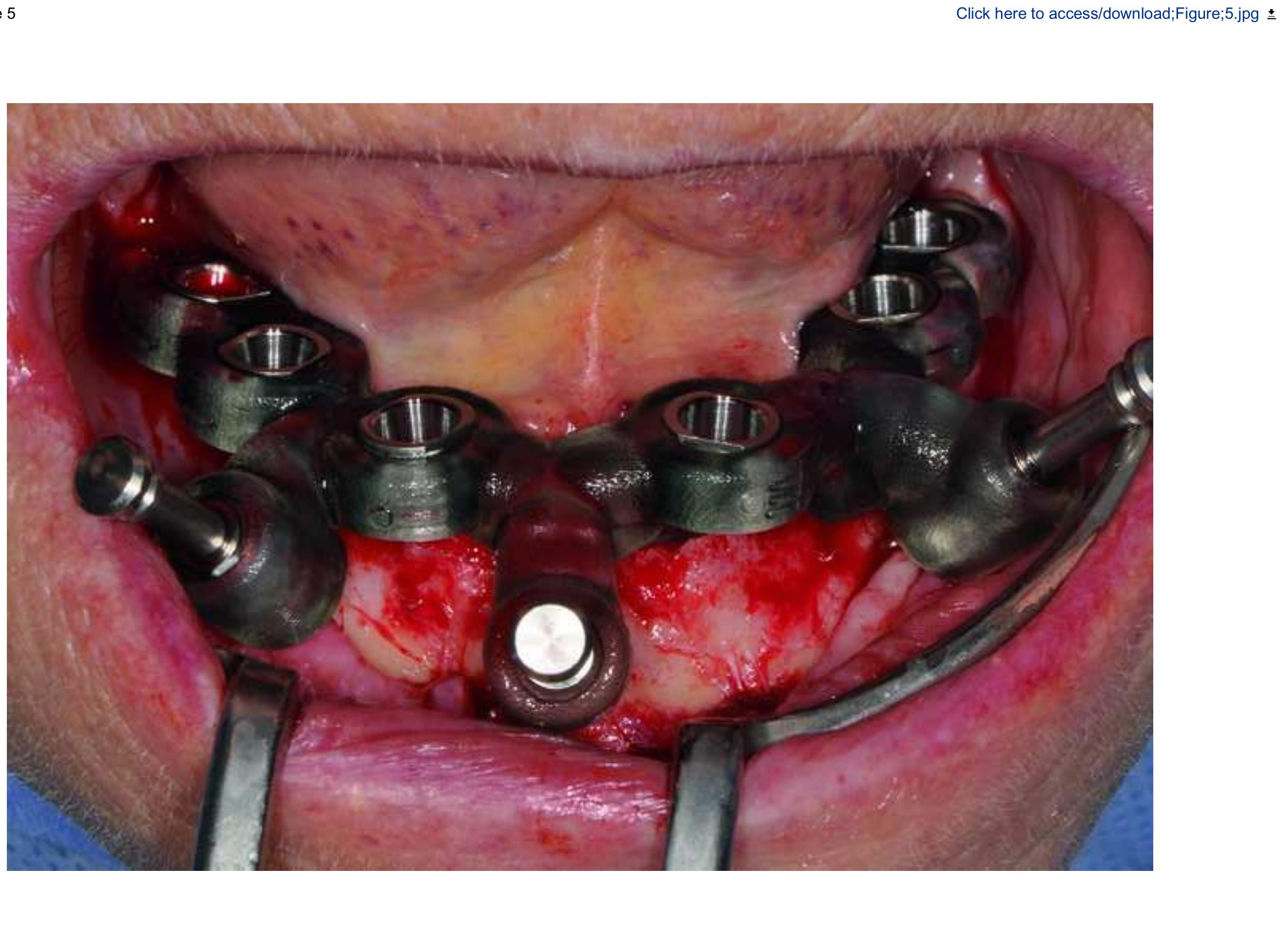

.




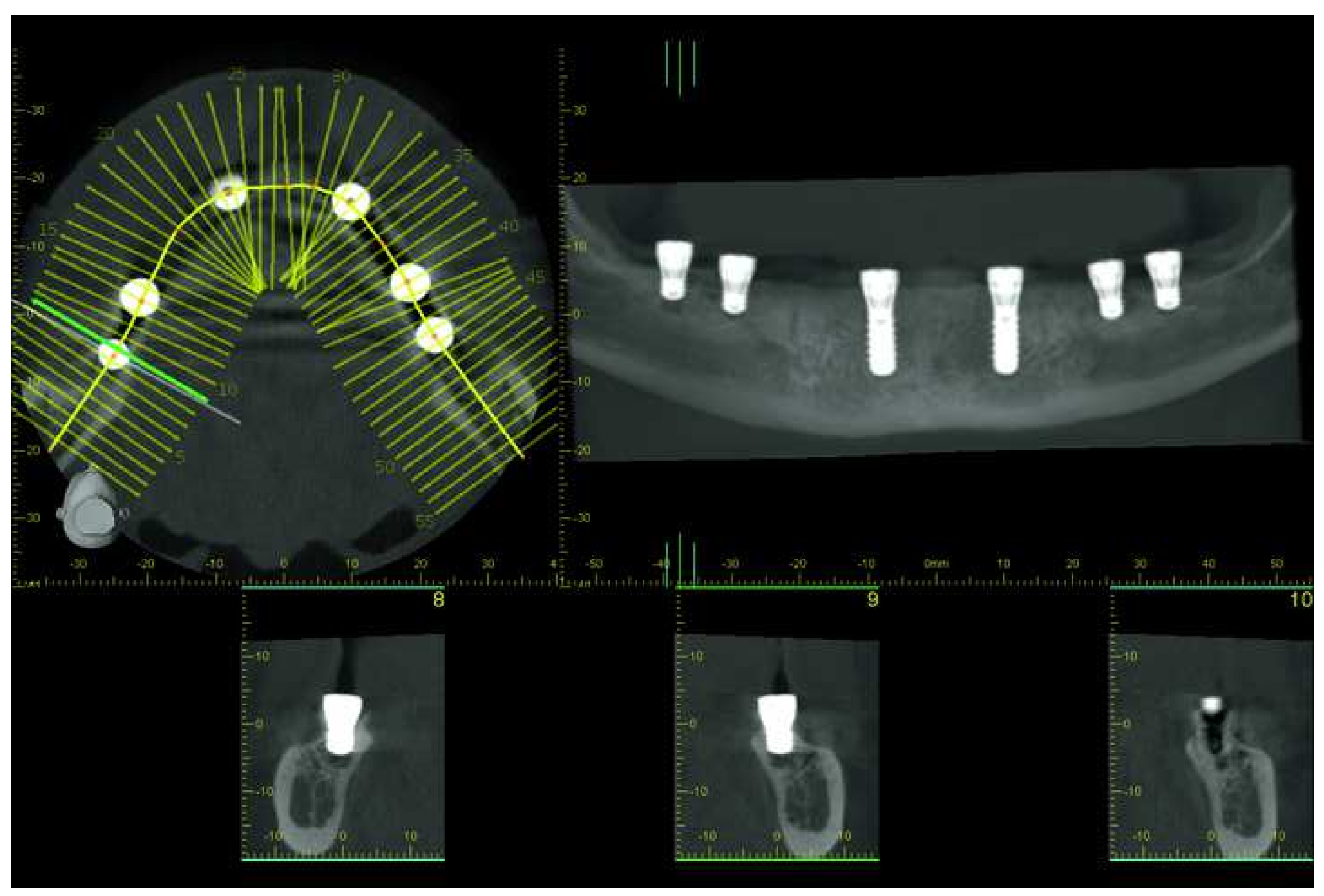


Figure $7 a$
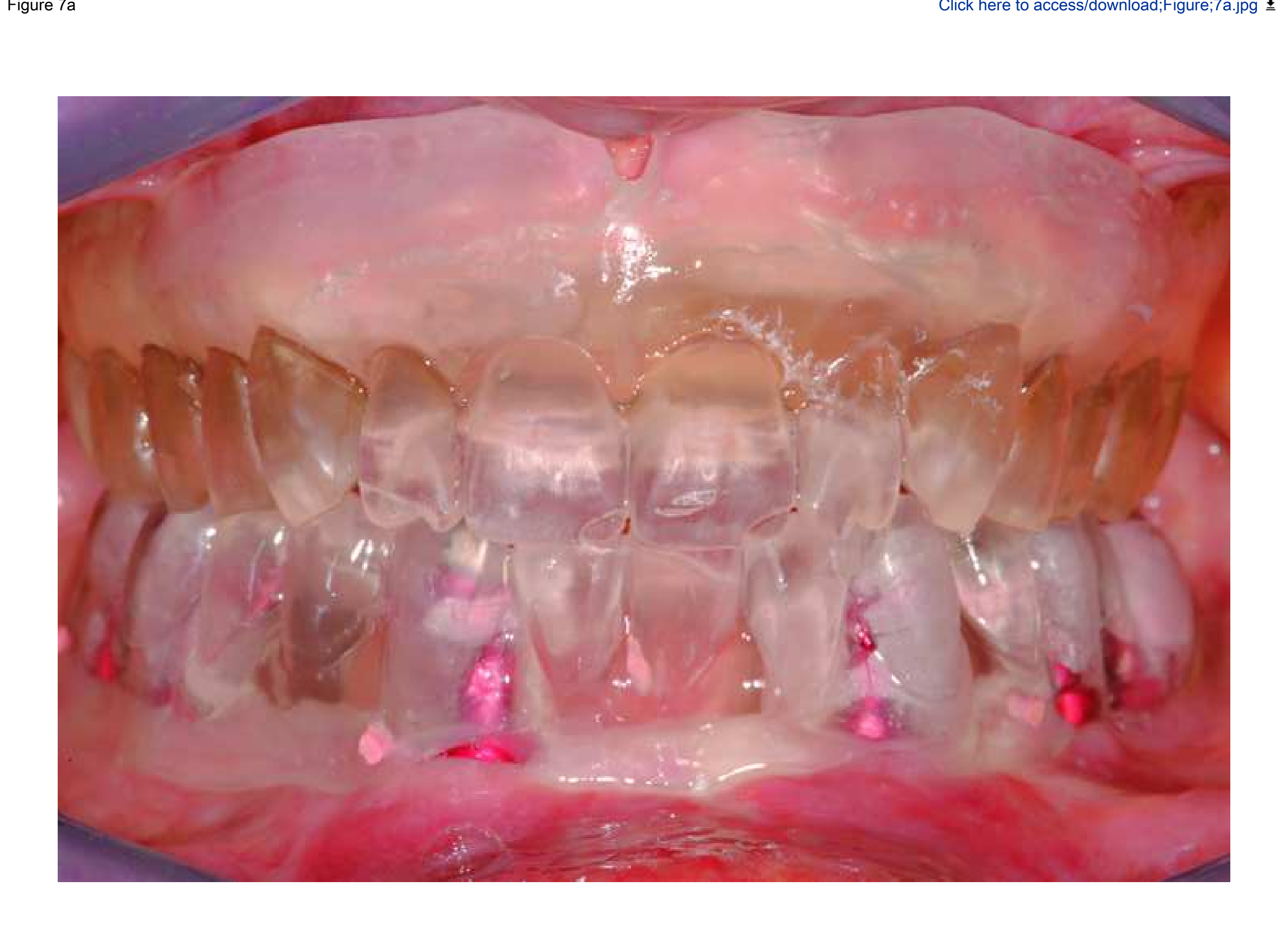

-

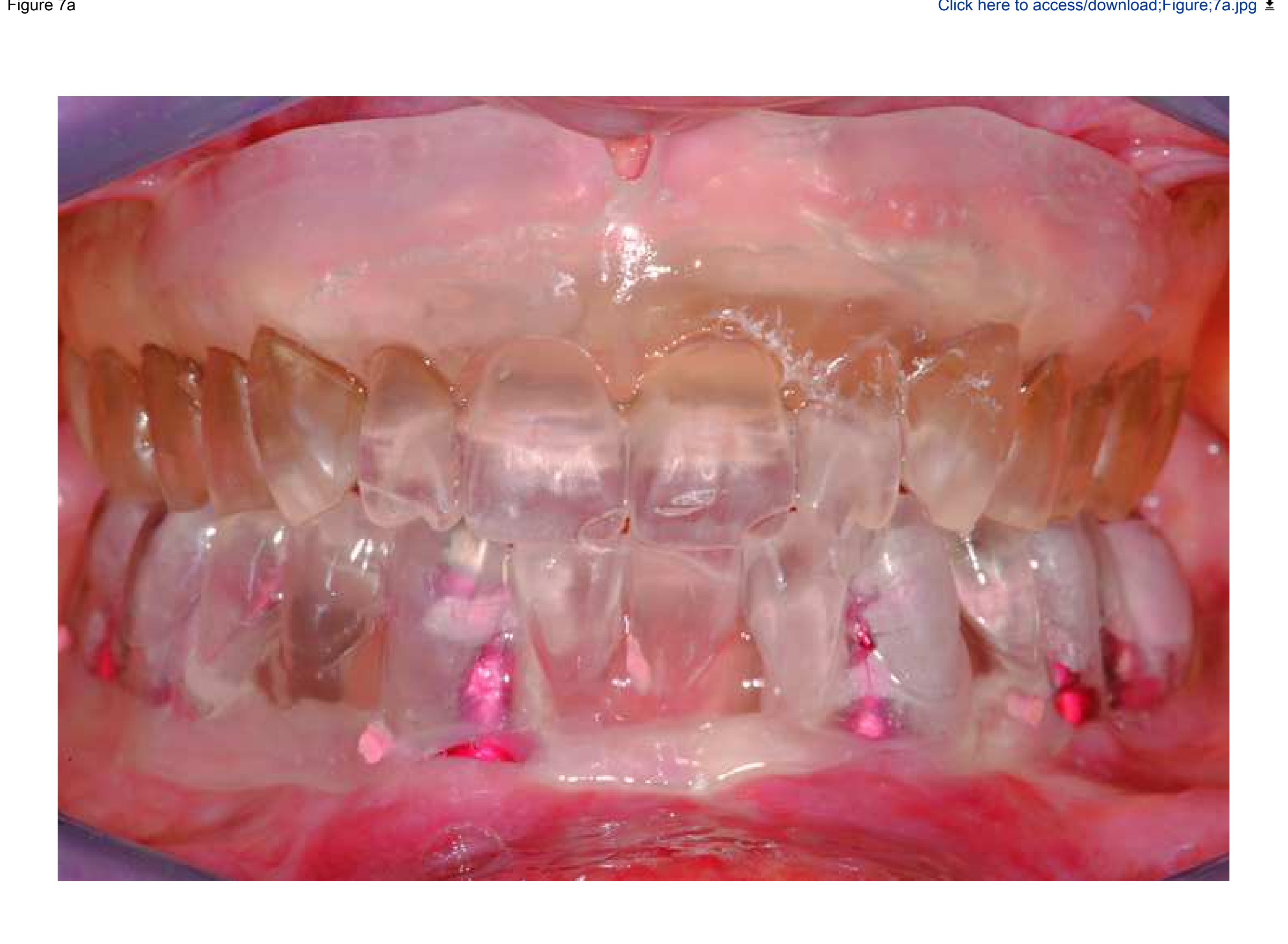

\section{.}

\section{Click here to access/download;Figure;7a.jpg $\underline{\underline{\Perp}}$}




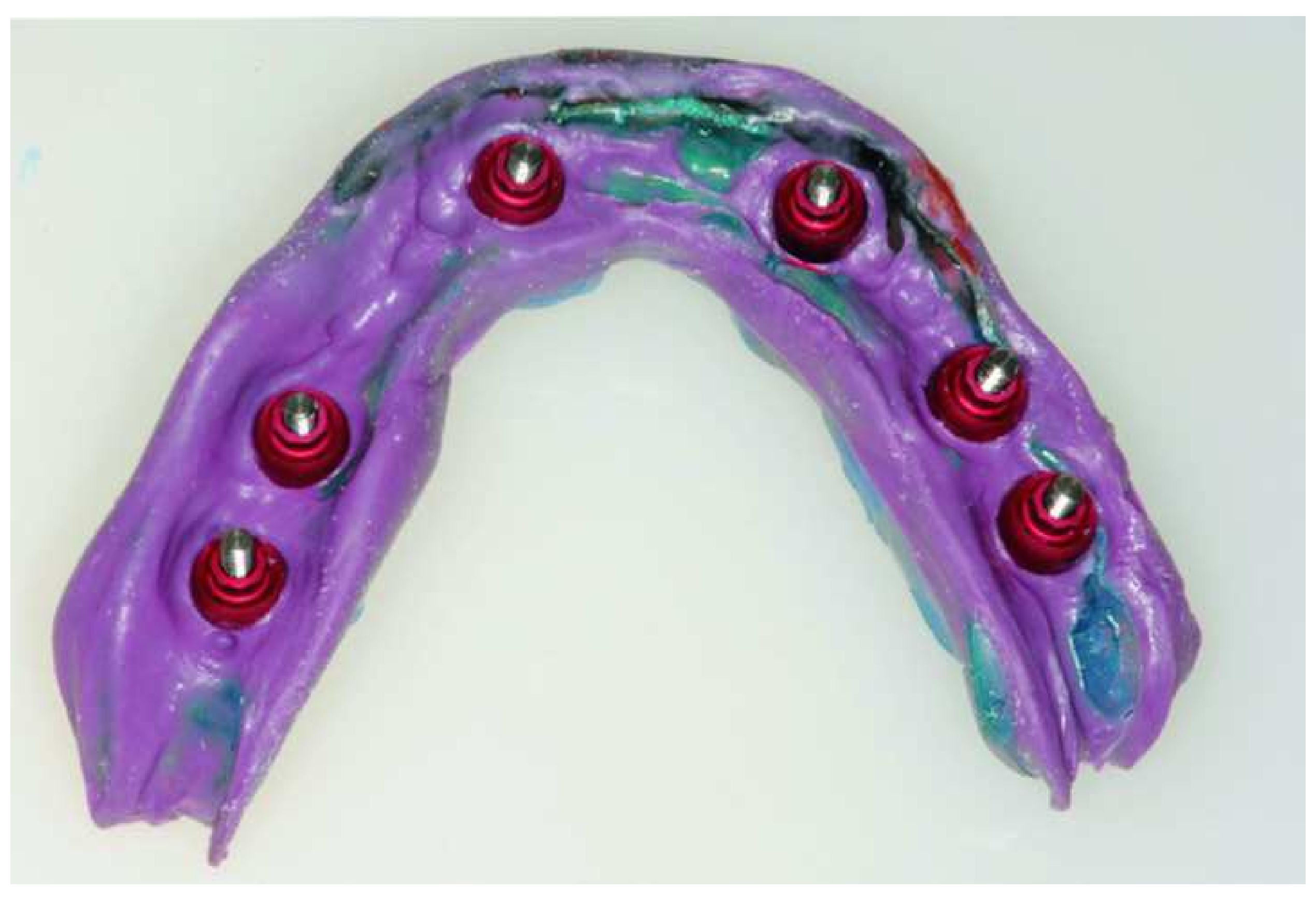

b

\section{Click here to access/download;Figure;7b.jpg $\underline{\underline{\boldsymbol{t}}}$

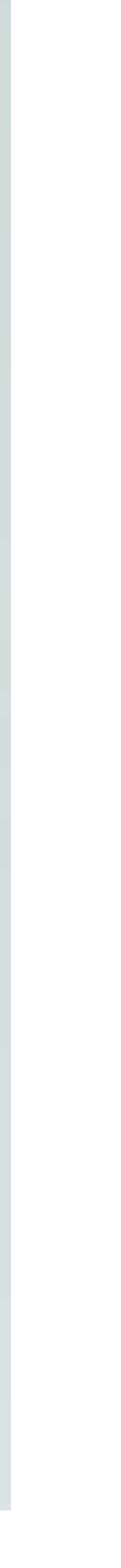


Figure $8 a$

Click here to access/download;Figure;8a.jpg $\underline{\underline{ \pm}}$

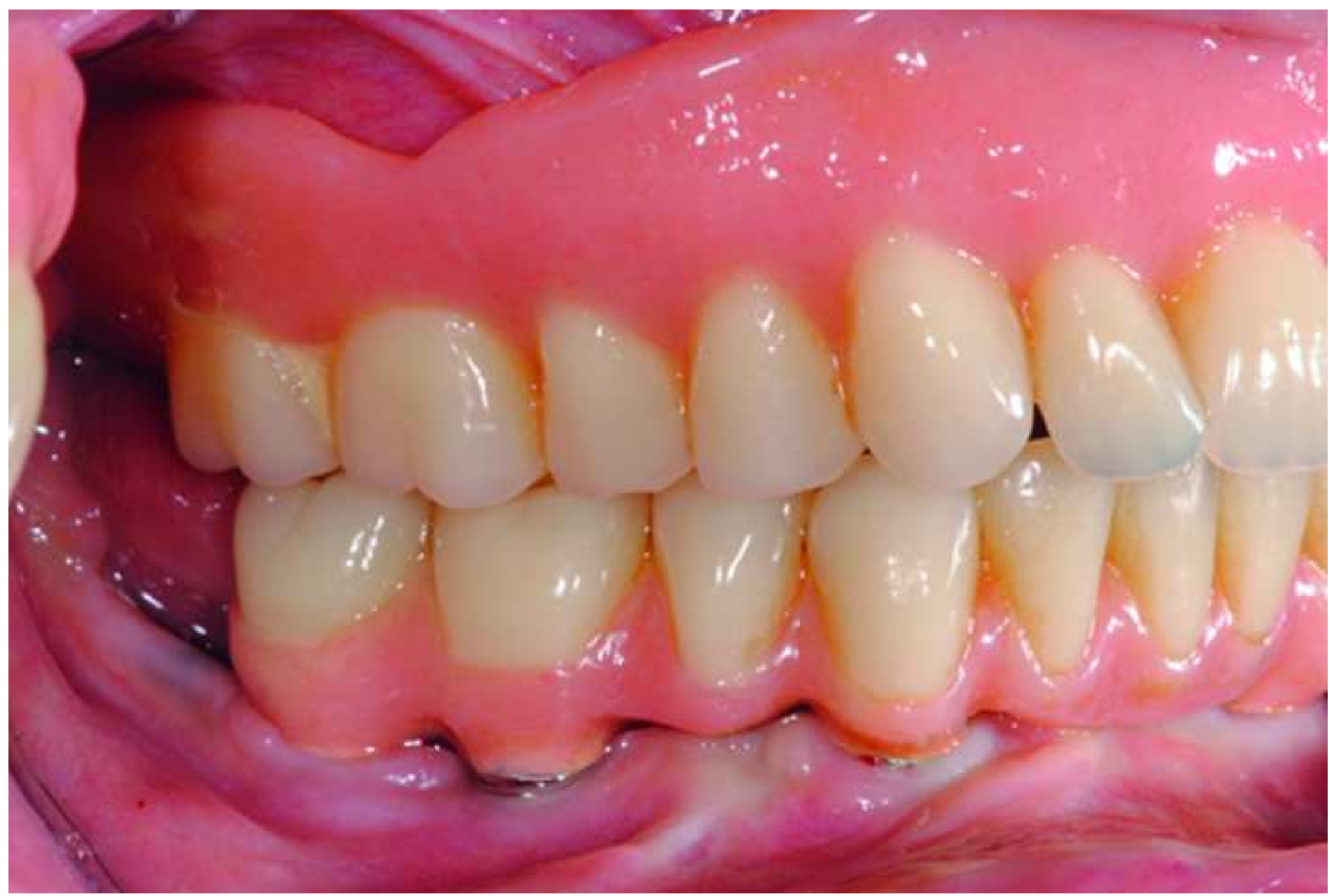




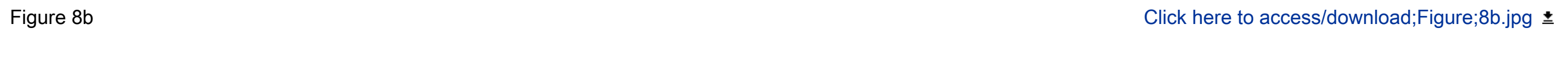

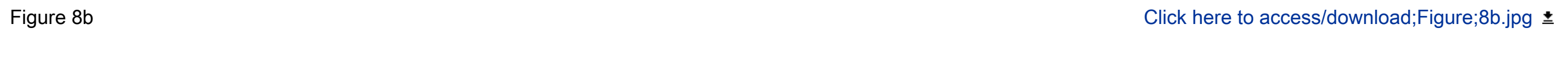

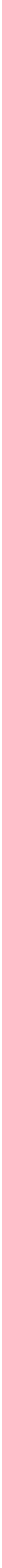

$$
\begin{aligned}
& \quad 8: 5 \\
& \because \because .
\end{aligned}
$$
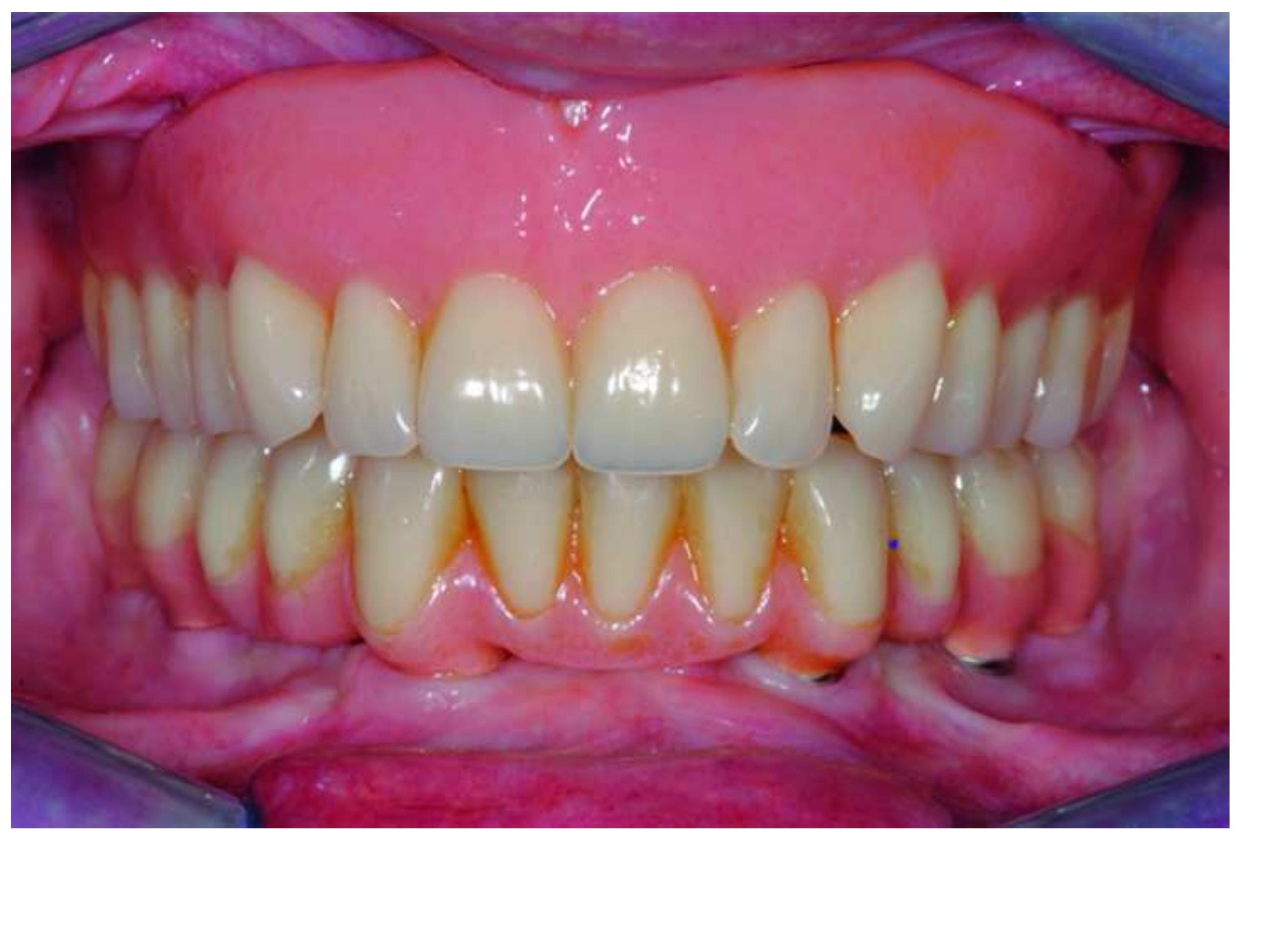


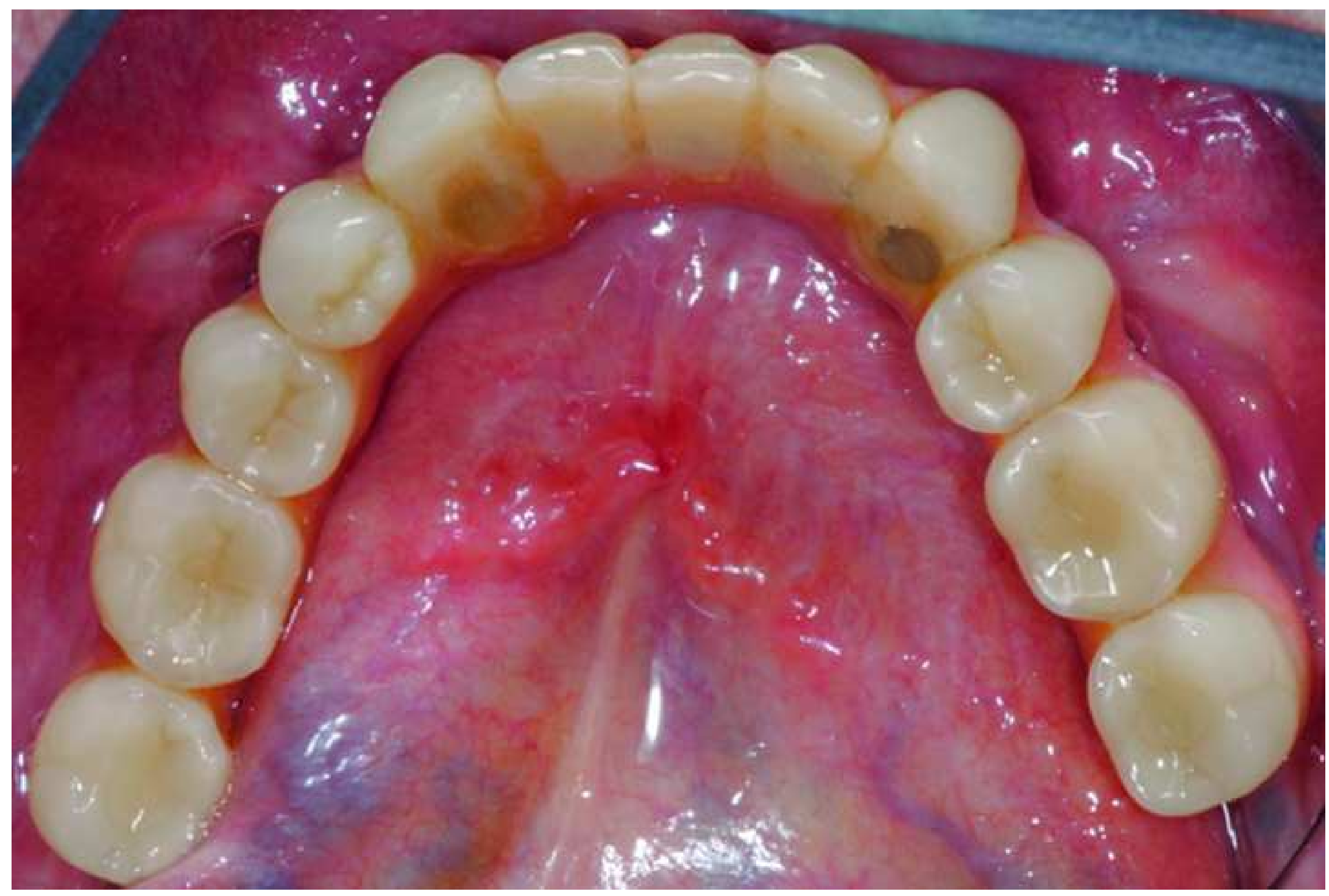


Figure $8 d$

Click here to access/download;Figure;8d.jpg $\underline{\underline{ }}$

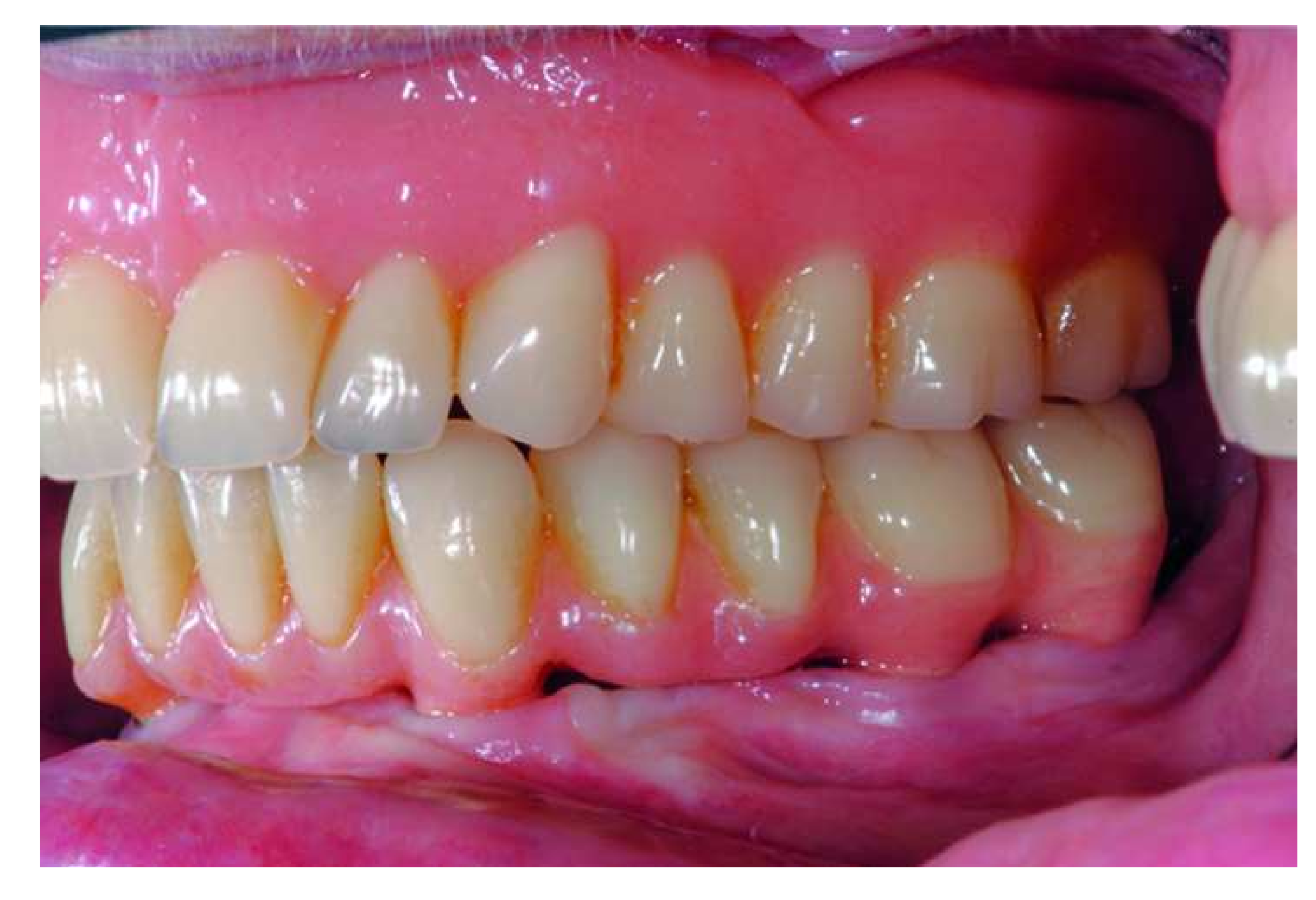

\section{.}

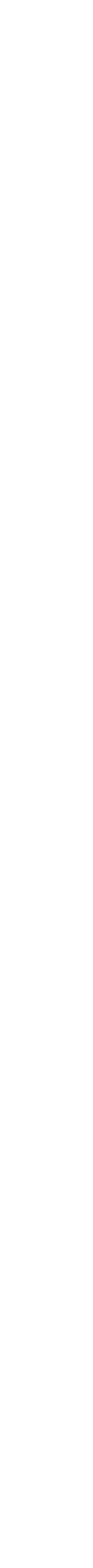




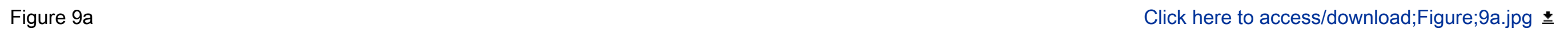

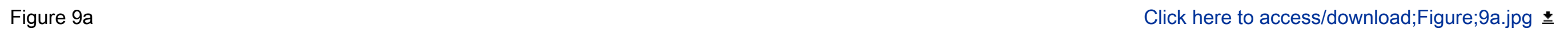

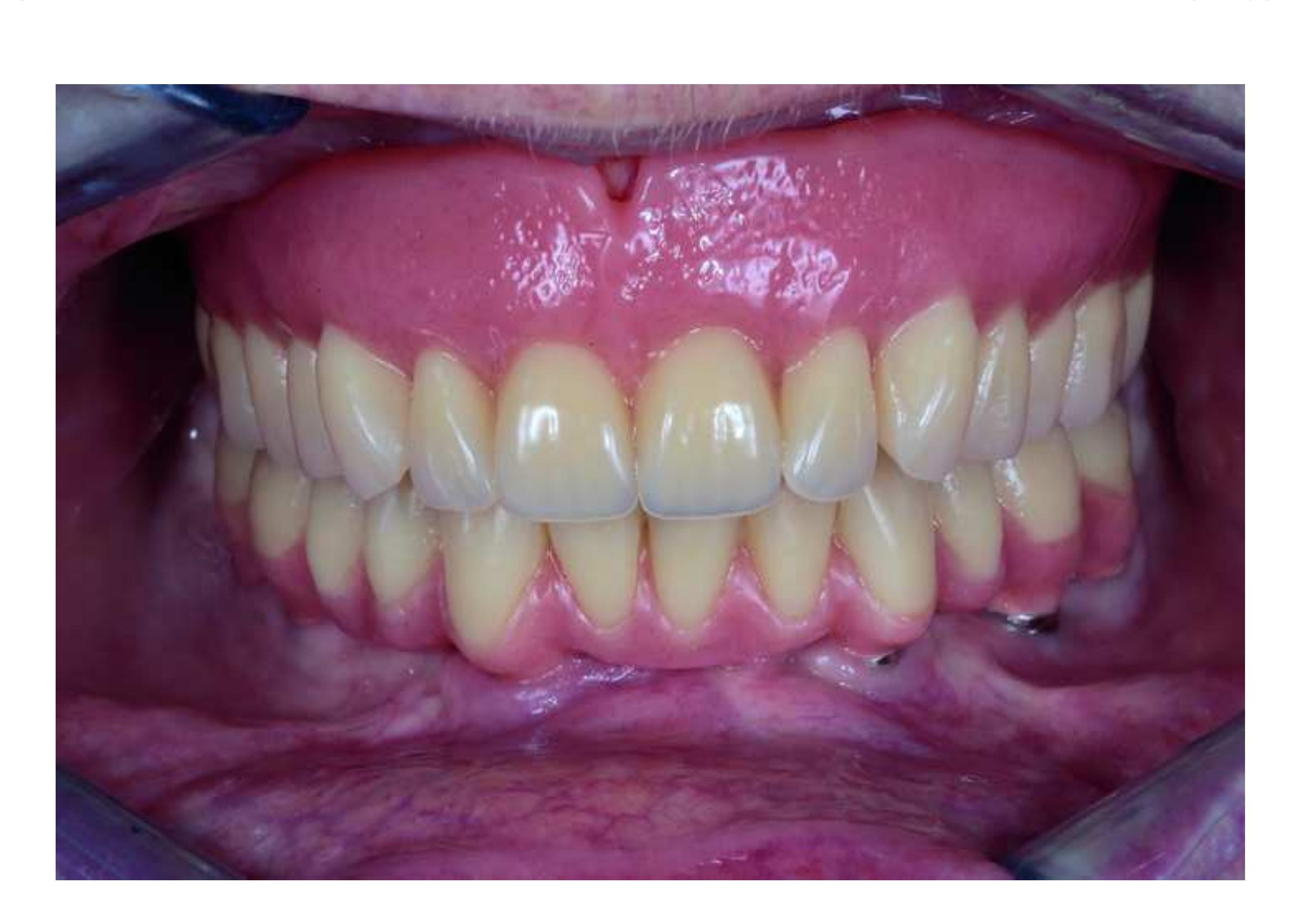

,

$$
.4
$$
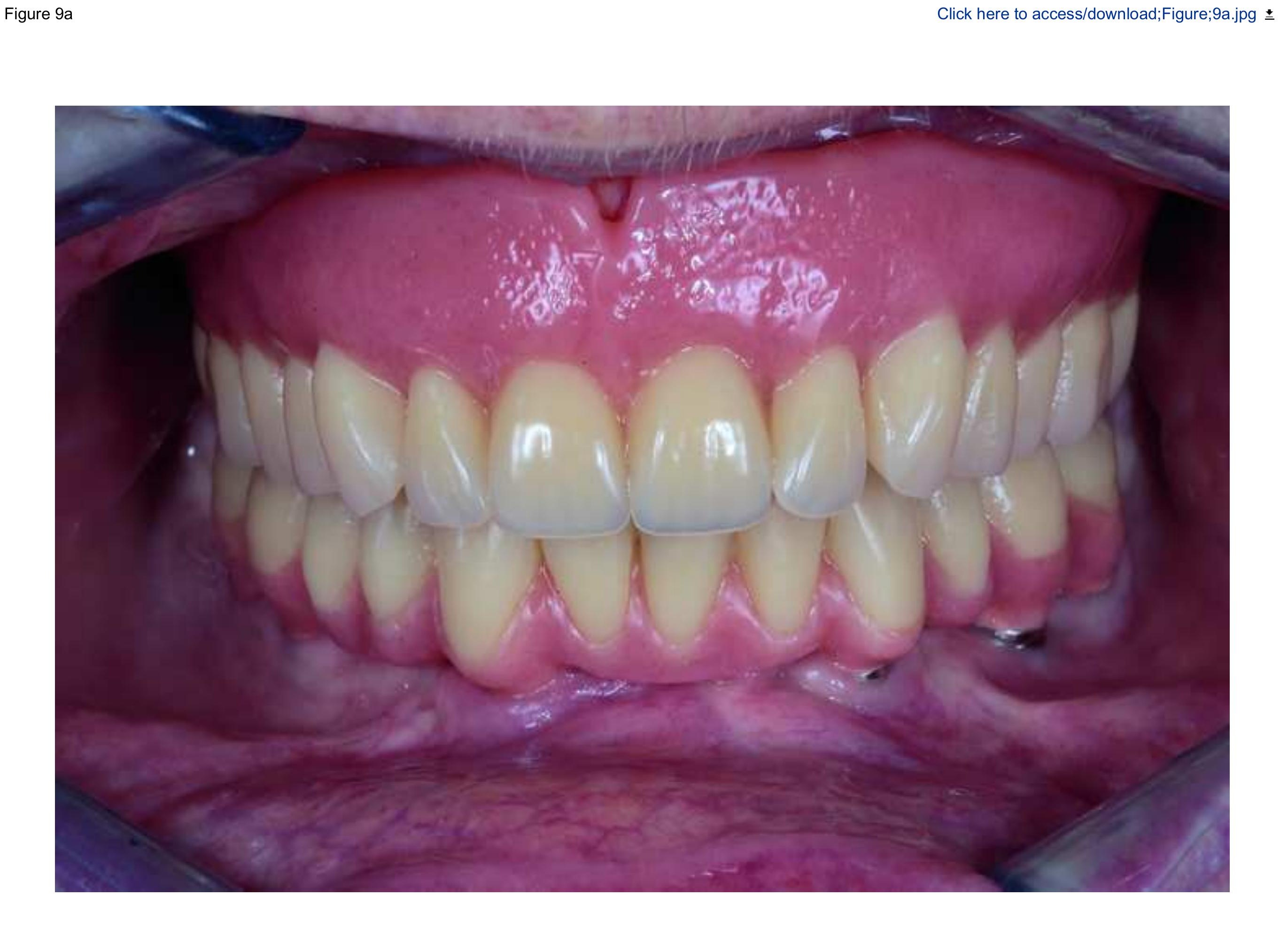
Figure $9 b$

Click here to access/download;Figure;9b 36m.jpg \pm

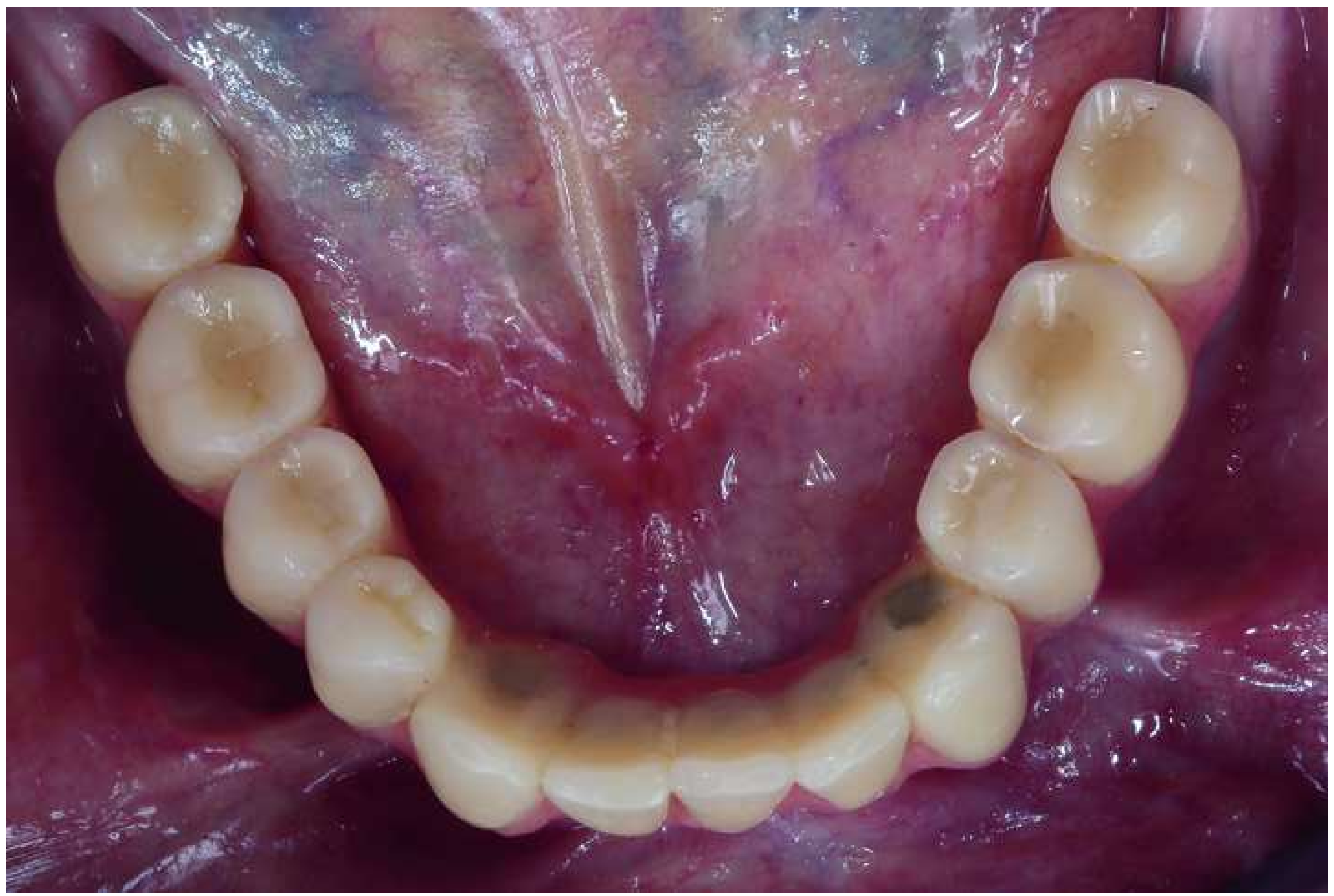




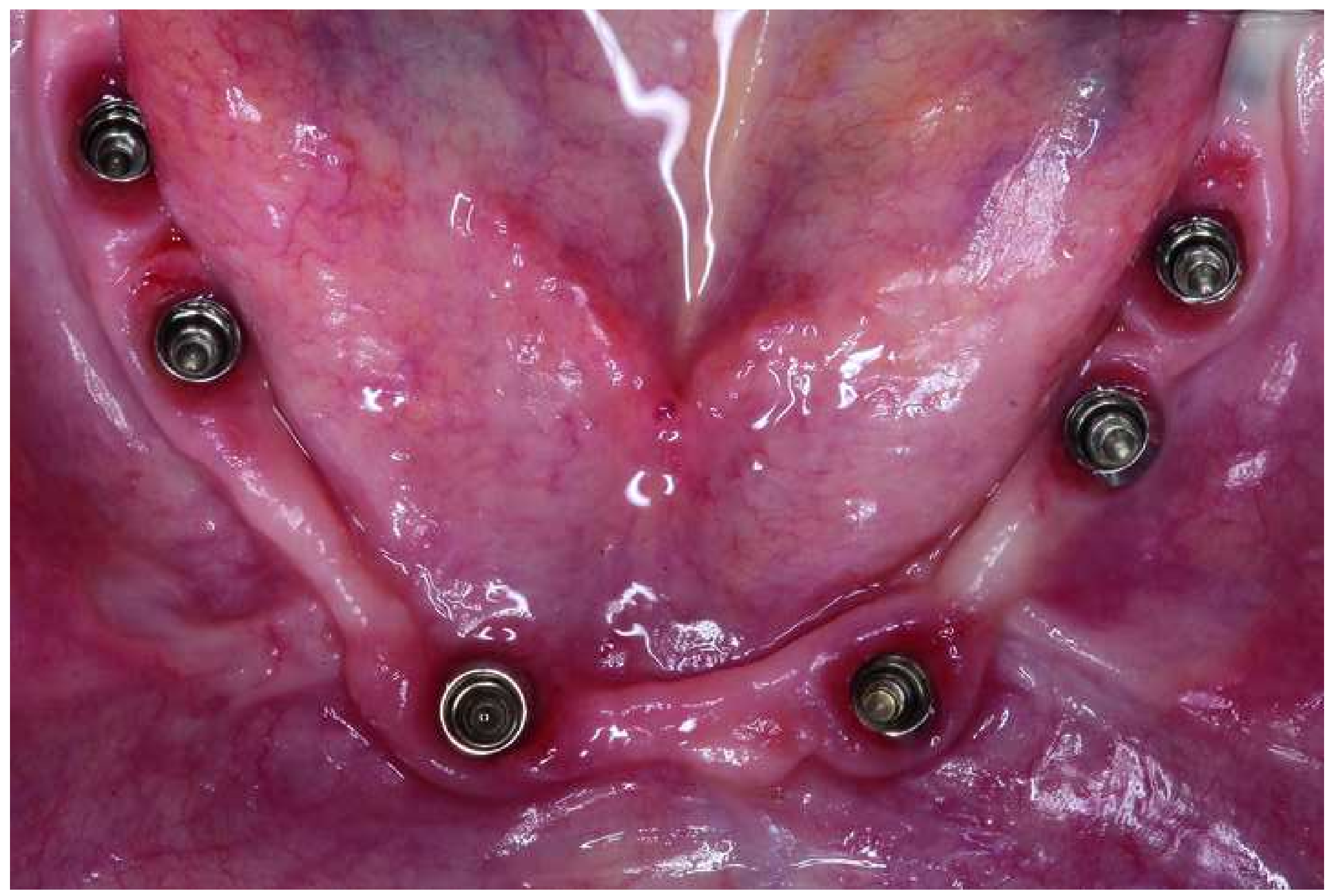


